\title{
SERVICEABILITY PERFORMANCE OF COMPOSITE CELLULAR BEAMS WITH PARTIAL SHEAR CONNECTION
}

\author{
R M Lawson The Steel Construction Institute and University of Surrey, UK \\ Corresponding author: Silwood Park, Ascot SL5 7QN m.lawson@steel-sci.com \\ D Lam School of Engineering, University of Bradford, UK \\ E Aggelopoulos The Steel Construction Institute, UK \\ F Hanus $\quad$ Arcelormittal Global R\&D, Luxembourg
}

\begin{abstract}
For composite cellular beams, additional deflections occur due to the loss of bending and shear stiffness at the opening positions and also due to slip in the shear connectors caused by partial shear connection. Design formulae are presented for the additional deflection of composite beams with cut circular openings or for cut and re-welded cellular beams as a function of the proportionate depth of the openings. The simplified formulae are calibrated against finite element results for both cellular and solid web beams and also against measured deflections of a $15.3 \mathrm{~m}$ composite cellular beam test. This additional deflection is presented as a function of flexural and shear terms that are a function of the span: depth ratio. For modelling of cellular beams to determine deflections, the circular opening may be represented by an equivalent rectangular opening of length equal to $0.7 \mathrm{x}$ opening diameter.
\end{abstract}

\section{Introduction}

Cellular beams with regular circular openings can be formed by cutting and re-welding rolled Isections or by cutting openings in a fabricated section or even a rolled section. Cellular beams may be designed compositely and are widely used as long span secondary beams that are supported by shorter span primary beams, as shown in Figure 1. Asymmetric cellular sections, as shown in Figure 2, may be made by welding a heavier bottom Tee to a lighter top Tee and are more efficient when used in composite construction.

The design of composite beams is presented in BS EN 1994-1-1: Eurocode 4 (1) and in the former BS 5950-3 (2) as well as in the AISC 360-10 Codes (3). The rules in these Codes concentrate on the design at the ultimate limit state and on the methods of achieving longitudinal shear connection. The design of composite beams with regular openings is not covered in detail by these standards and so designers have to use additional guidance, such as those given in SCI P355 (4) and in the Steel Design Guide by the AISI (5). Rules for the design of beams with large web openings at the serviceability limit state are more approximate and the development of suitable design rules for serviceability of composite cellular beams is the scope of this paper.

The design of composite beams with large web openings has been the subject of extensive research over the last 20 years and design recommendations have been prepared in the USA by Darwin (5) and in the UK in SCI publication 355 (4), based on the work by Lawson et al (7). For analysis under the effects of shear, a circular opening may be treated for Vierendeel bending as an equivalent rectangular opening of length $0.45 h_{0}$, based on the early work of 
Redwood (8). This paper presents an evaluation of the effective opening size for deflection calculations taking account of bending and shear actions.

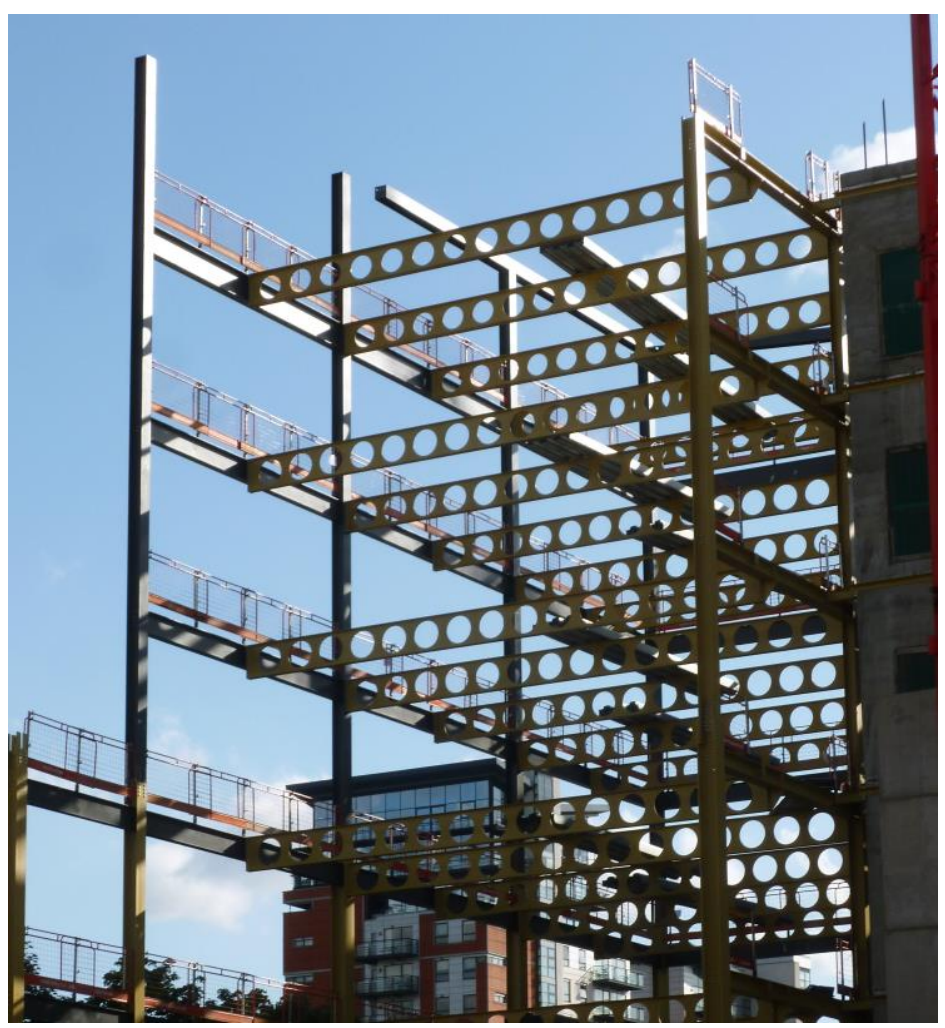

Figure 1 Cellular beams with large web openings used as long span secondary beams

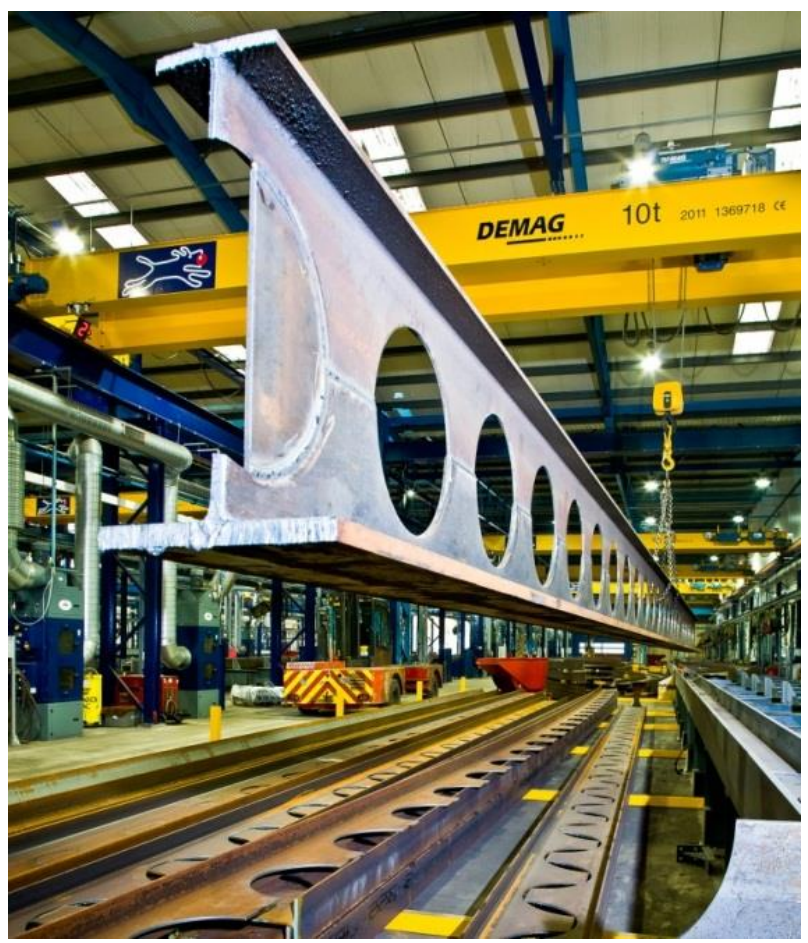

Figure 2 Fabrication of asymmetric cellular beam

\section{Shear Connection in Composite Cellular Beams}


At the ultimate limit state, the design of composite cellular beams is normally based on plastic analysis principles in which the tensile resistance of the bottom Tee section is compared to compression resistance of the concrete slab acting across its effective width. Where the longitudinal force developed due to the combined resistance of the shear connectors is insufficient to develop the compression resistance of the slab or the tensile resistance of the bottom Tee, this is known as 'partial shear connection'.

Unlike a solid web beam, it is not necessary to develop plasticity in the missing web in order to reach the bending resistance of the composite beam. This means that the strains in the bottom flange required to develop the plastic bending resistance of the composite cellular beam section are lower than those needed for a solid web beam. Therefore, it is possible to reduce the minimum degree of shear connection for cellular beams based on a limiting end slip in comparison with solid web beams. However, there are no specific codified rules for shear connection in cellular beams in Eurocode 4 (1) or in the former BS 5950-3 (2).

\subsection{Minimum degree of shear connection}

Eurocode 4 clause 6.6.1.2 presents rules for the minimum degree of shear connection that are based on a limiting end slip of $6 \mathrm{~mm}$ at the plastic resistance of the beam which is considered to be propped during construction so that all loads are applied to the composite section . In the recent SCI publication 405 (6), which was produced to complement the use of Eurocode 4 for design in the UK, the minimum degree of shear connection is reduced for un-propped solid web beams and for shear connectors with a higher limiting end slip of $10 \mathrm{~mm}$. No guidance is presented on the effect of partial shear connection on additional deflections.

In a recent RFCS project, DISCCo (10) in which the authors participated, a modification factor for the minimum degree of shear connection for cellular beams was proposed based on extensive finite element investigations, and is a function of the relative opening size and asymmetry of the steel flanges. For design purposes, the minimum degree of shear connection of a cellular beam, $\eta_{\text {cellular }}$, may be reduced (10) by modifying the current Eurocode 4 rules for the equivalent solid web beam, as follows:

$$
\eta_{\text {cellular }}=\eta_{E C 4} \cdot\left(1-\frac{0.7 h_{o}}{h} \frac{A_{f t}}{A_{f b}}\right)
$$

where $\eta_{E C 4}$ is the minimum degree of shear connection for the equivalent solid web beam

$h_{0}$ is the opening height

$h$ is the beam height

$A_{\mathrm{ft}}$ is top flange area

$A_{\mathrm{fb}}$ is bottom flange area $\geq A_{\mathrm{ft}}$

The use of this formula only applies when the bending resistance of the composite cellular beam is calculated at the centre-line of the opening. The higher the relative flange areas, the lower the plastic neutral axis in the composite section which increases the slip in the shear connectors and reduces the effect of the opening on the development of the plastic bending resistance. Hence, this design formula shows in an approximate manner how the relative flange area affects the minimum degree of shear connection that may be used. As an 
example, for $h_{\mathrm{o}} / \mathrm{h}=0.7$ and $\mathrm{A}_{\mathrm{fb}} / \mathrm{A}_{\mathrm{ft}}=2$, the modification factor on the minimum degree of shear connection of the equivalent solid web beam is $\times 0.75$. 


\subsection{Additional deflections due to the flexibility of the shear connectors}

In cases of partial shear connection, slip occurs at the interface between the beam and slab due to the flexibility of the shear connectors, which leads to additional deflections. The means of taking account of the flexibility of the shear connectors on the elastic properties of composite beams is potentially complex and so simplifications may be made for design purposes. The theory of partial shear connection applies to both solid web and perforated beams.

In the former BS 5950-3, the additional deflection, $w_{\text {add }}$, due to the effects of slip caused by partial shear connection in un-propped composite beams was given by a relatively simple equation, as follows:

$$
\mathrm{w}_{\text {add }}=0.3(1-\eta)\left(\mathrm{w}_{\mathrm{s}}-\mathrm{w}_{\mathrm{comp}}\right)
$$

Where
$\mathrm{W}_{\text {comp }}$ is the deflection of the composite beam for rigid shear connectors (no slip) at the serviceability load (using the Eurocode symbol, w, for deflection)
$\mathrm{w}_{\mathrm{s}}$ is the deflection of the steel beam for the same serviceability loading
$\eta$ is the degree of shear connection of the beam at the ultimate limit state

The empirical factor of 0.3 applies to un-propped beams subject to imposed loads. For propped beams, the factor is increased to 0.5 to take account of the non-linear behaviour of the shear connectors when self-weight loads also act on the composite section. In Eurocode 4 , it is not required to take account of additional deflections provided that at least $50 \%$ degree of shear connection is provided. The argument made was the effects of slip are counteracted by the stiffening effects of continuity in practical applications. No guidance is offered in Eurocode 4 as to how to calculate deflections for lower degrees of shear connection.

The first theory for the effects of partial shear connection on the design of composite beams with partial shear connection was developed by Newmark et al. (12), who presented a solution of a differential equation linking slip and deflection for beams. The differential equation may also be solved using finite difference method and many papers have presented this approach, such as those by Lam et al. (13), Ranzi and Zona (14) and Ranzi at al. (15).

For flexible shear connectors, the effective second moment of area $l_{\text {eff }}$ of a composite beam taking account of end slip was presented by Lawson et al. (7) for the case of uniformly distributed loading. The effective stiffness is a function of the shear stiffness, $\mathrm{k}_{\mathrm{sc}}$, of the shear connectors and other properties of the cross-section, as given in equation (3). The inertia of a composite beam with rigid shear connectors, $I_{\text {comp }}$ is obtained by setting the stiffness of the shear connectors to infinity so that the last term in the denominator is zero.

$$
I_{\text {eff }}=I_{s}+\frac{I_{c}}{n}+\frac{\left(y_{s}+0.5 h_{c}+h_{p}\right)^{2}\left(\frac{A_{c}}{n}\right)}{\left[1+\frac{A_{c}}{n A_{s}}+\left(\frac{\pi}{L}\right)^{2}\left(\frac{E_{s}}{k_{s c} / s_{s c}}\right)\left(\frac{A_{c}}{n}\right)\right]}
$$

Where $A_{\mathrm{s}} \quad$ is the cross-sectional area of the steel beam 


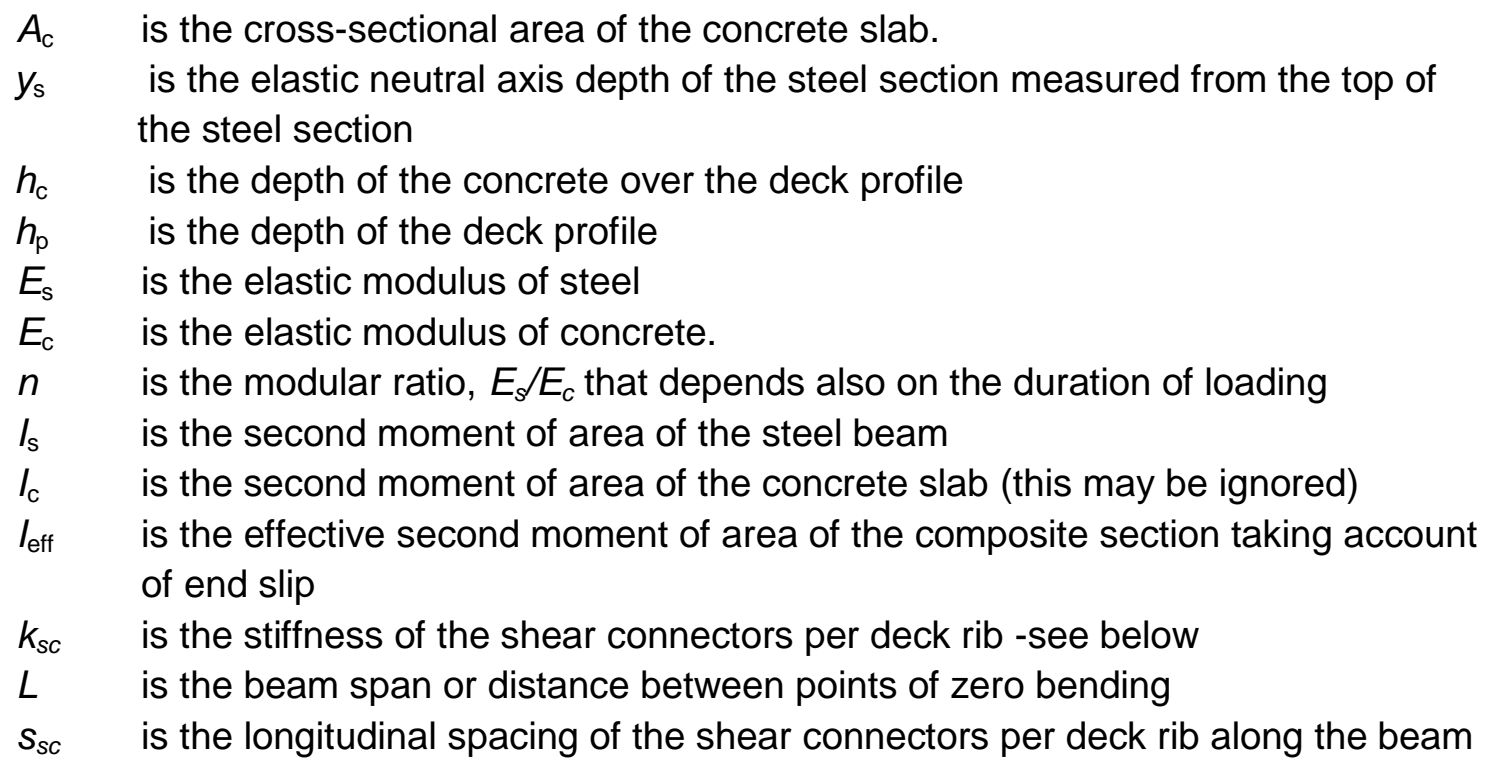

The initial elastic stiffness of single and pairs of shear connectors was obtained from the results of push-out tests carried out in the DISCCo project (10) for $19 \mathrm{~mm}$ diameter through deck welded shear connectors, deck profiles of $58 \mathrm{~mm}$ and $80 \mathrm{~mm}$ depth and with nominally C30/37 concrete. For un-propped construction, the imposed loading at the serviceability limit state is approximately $40 \%$ of the factored loading and so the elastic stiffness of the shear connectors was obtained at this proportion of the shear connector resistance. From these tests, it was concluded that for design purposes, the representative stiffness, $k_{\mathrm{sc}}$ obtained from the push tests may be taken as $70 \mathrm{kN} / \mathrm{mm}$ for single shear connectors and $100 \mathrm{kN} / \mathrm{mm}$ for pairs of shear connectors per deck rib for the two deck profiles, which covers the normal range of application.

For beams that are propped during construction, higher loads are applied to the shear connectors at the serviceability limit state. The elastic stiffness was obtained at a load corresponding to $60 \%$ of the failure load, and because of the slight non-linear behaviour of the shear connectors, the representative stiffness, $k_{\mathrm{sc}}$ reduces to $60 \mathrm{kN} / \mathrm{mm}$ for single shear connectors and $80 \mathrm{kN} / \mathrm{mm}$ for pairs of shear connectors.

\section{Deflection of composite beams with large web openings}

For composite beams with web openings, additional deflections at the serviceability limit state occur due to:

- Loss of flexural stiffness due to the loss of part of the web in bending. This effect is greater in a composite beam than in a steel beam because the neutral axis depth is higher in the section and the web contributes more to the stiffness.

- Loss of shear area, which adds to the pure shear deflection and causes additional deflections due to Vierendeel bending across the circular openings and to web-post bending between openings.

- Effects of partial shear connection, as defined by equation (3) but using the properties of the composite beam at the centre-line of the openings.

\subsection{Current formulae for additional deflection of cellular beams}


The combined effect of the multiple circular openings leads to additional bending and shear deflections, but the precise increase is not amenable to hand calculations. The additional deflection relative to an equivalent solid web beam is influenced by proportionate opening depth and web-post width, and for composite beams, also by local composite action at the openings, which affects both the flexural and shear behaviour.

In SCI publication 355 (4), an approximate formula for the additional deflection of a composite cellular beam relative to the equivalent solid web beam was derived from a numerical assessment of composite beams using symmetric l-sections with various opening sizes. This was given as:

$$
\frac{w_{\text {add }}}{w_{b}}=0.47 n_{o}\left(\frac{h_{o}}{h}\right)^{2}\left(\frac{h}{L}\right)
$$

Where

$$
\begin{aligned}
& w_{\text {add }} \text { is the additional mid-span deflection due to the series of circular openings } \\
& w_{\text {comp }} \text { is the mid-span deflection of the solid web composite beam } \\
& n_{0} \text { is the number of circular openings in the span of the beam } \\
& h_{0} \text { is the opening diameter } \\
& h \text { is the depth of the steel section }
\end{aligned}
$$

As an example, for $h_{0} / h=0.7$ and $n_{0}=L / h$, the additional deflection relative to the equivalent solid web beam is $24 \%$. The precise effect of circular openings on additional deflections in composite cellular beams of a range of cross-sectional proportions is investigated in more detail in this paper, and is compared to the results of a long span cellular beam test. This leads to new design formulae that are more accurate over the full range of opening sizes.

\subsection{Study of the influence of opening depth on pure bending deflection}

The influence of the opening depth on the flexural stiffness of composite beams was assessed by calculation for a range of rolled beam sizes for spans of 9 to $15 \mathrm{~m}$. The second moment of area of the perforated composite beam $I_{\text {comp,o }}$ was calculated at the centre-line of the openings in two generic forms of beams with web openings (a) Cut openings in IPE beams and (b) Cut and re-welded IPE beams to form deeper cellular beam sections. For calculation purposes, the composite stiffness was obtained for rigid shear connectors which represents the case where the elastic neutral axis is at its highest position and therefore the effect of the openings on the composite inertia is greater than for cases of partial shear connection.

In this study, the beam span: depth (L/h) ratio of the beams was 20 to 25 , which covers the practical range of application. The slab depth was taken as $130 \mathrm{~mm}$ with a $60 \mathrm{~mm}$ deep deck profile and the effective width is taken as $5 \mathrm{~h}$, which approximates to $\mathrm{L} / 4$. The modular ratio, $n$, of steel to concrete was taken as 10 , which is a typical value when considering imposed load deflections.

The results are presented in Table 1 for composite beams using rolled IPE 400 to 600 sections and with cut openings. The effect of the proportionate opening depth, $h_{0} / h$, is also dependent on the position of the elastic neutral axis, which for a composite section is close to 
the top flange. The calculations were repeated for a $150 \mathrm{~mm}$ deep slab with $80 \mathrm{~mm}$ deep decking and it was found that the effect of the parameter $h_{o} / h$ on the reduced inertia of the beam was similar.

Based on these results for rolled sections with cut openings, the bending deflection of a composite section with a notionally continuous loss of web of depth, $h_{0}$ is dependent the inverse of the ratio of the inertia of the perforated beam to the equivalent solid web beam -see the data in Table 1. It is shown that for this case, the additional deflection due to loss of bending stiffness for rolled beam with cut openings is given approximately by:

$$
\mathrm{w}_{\mathrm{b}, \text { add }}=\mathrm{w}_{\text {comp }} 0.4\left(\frac{h_{o}}{h}\right)^{1.5}
$$

Table 1: Influence of opening size on bending deflection of a composite beam using rolled sections with cut web openings for openings of proportionate depth, $h_{o} / h$

\begin{tabular}{|c|c|c|c|c|c|c|c|}
\hline \multirow{2}{*}{$\begin{array}{c}\text { Beam } \\
\text { Span/Spacing }\end{array}$} & \multirow{2}{*}{$\begin{array}{l}\text { Beam } \\
\text { Size }\end{array}$} & \multicolumn{5}{|c|}{ Ratio: $I_{\text {comp }, 0} / I_{\text {comp }}$ for: } & \multirow{2}{*}{$I_{\text {comp } / I_{s}}$} \\
\hline & & $\mathrm{h}_{\mathrm{o}} / \mathrm{h}=0.4$ & $=0.5$ & $=0.6$ & $=0.7$ & $=0.8$ & \\
\hline $9 \mathrm{~m} / 2.25 \mathrm{~m}$ & IPE 400 & 0.91 & 0.88 & 0.86 & 0.83 & 0.80 & 3.14 \\
\hline $12 \mathrm{~m} / 3 \mathrm{~m}$ & IPE 500 & 0.91 & 0.88 & 0.85 & 0.81 & 0.79 & 2.92 \\
\hline $15 \mathrm{~m} / 3.75 \mathrm{~m}$ & IPE 600 & 0.92 & 0.88 & 0.86 & 0.82 & 0.77 & 2.70 \\
\hline \multicolumn{2}{|c|}{$\begin{array}{l}\text { Increase in deflection due to } \\
\text { loss of flexural stiffness (\%) }\end{array}$} & $10 \%$ & $14 \%$ & $18 \%$ & $23 \%$ & $28 \%$ & \\
\hline \multicolumn{2}{|c|}{ deflection $=0.4\left(\frac{h_{o}}{h}\right)^{1.5}$} & $9 \%$ & $14 \%$ & $18 \%$ & $23 \%$ & $28 \%$ & \\
\hline
\end{tabular}

$I_{\text {comp }, 0}$ is the inertia of the perforated composite beam, $I_{\text {comp }}$ is the inertia of the solid web composite beam of the same depth, $I_{s}$ is the inertia of the solid web steel beam of the same size

The calculations were repeated for cellular beam sections that are formed by cutting and rewelding rolled IPE 300 to IPE 500 sections. In this case, the ratio $h_{\delta} / h$ was varied notionally for beams of 1.5 times the depth of the parent section, although in practice the proportional opening size would be fixed geometrically. Because the web area is increased for the same flange area, the loss of the web leads to a greater loss of stiffness for a cellular beam than a rolled beam with cut openings. The results for composite cellular beams are presented in Table 2.

It was found that for cellular beams, the additional deflection due to loss of bending stiffness of a composite beam due to the continuous loss of web of depth $h_{0}$ is given approximately by:

$$
\mathrm{w}_{\mathrm{b}, \mathrm{add}}=\mathrm{w}_{\mathrm{comp}} 0.5\left(\frac{h_{o}}{h}\right)^{1.5}
$$

This formula leads to higher additional bending deflections for cellular beams than for rolled sections with cut openings and may be used conservatively in all cases including fabricated beams. 

Table 2: Influence of opening size on bending deflection of a composite cellular beams for web openings of proportionate depth $h_{0} / h$

\begin{tabular}{|c|c|c|c|c|c|c|}
\hline \multirow{2}{*}{$\begin{array}{c}\text { Beam } \\
\text { Span/Spacing }\end{array}$} & \multirow{2}{*}{$\begin{array}{l}\text { Beam } \\
\text { Size }\end{array}$} & \multicolumn{4}{|c|}{ Ratio: $I_{\text {comp }, o} / I_{\text {comp }}$ for: } & \multirow{2}{*}{$I_{\text {comp } /} I_{s}$} \\
\hline & & $\mathrm{h}_{\mathrm{o}} / \mathrm{h}=0.5$ & $=0.6$ & $=0.7$ & $=0.8$ & \\
\hline $9 \mathrm{~m} / 2.25 \mathrm{~m}$ & $\begin{array}{l}\text { IPE } 300 \text { formed into } \\
450 \mathrm{~mm} \text { cellular beam }\end{array}$ & 0.82 & 0.80 & 0.77 & 0.72 & 3.27 \\
\hline $12 m / 3 m$ & $\begin{array}{l}\text { IPE } 400 \text { formed into } \\
600 \mathrm{~mm} \text { cellular beam }\end{array}$ & 0.85 & 0.82 & 0.78 & 0.73 & 2.83 \\
\hline $15 \mathrm{~m} / 3.75 \mathrm{~m}$ & $\begin{array}{l}\text { IPE } 500 \text { formed into } \\
750 \mathrm{~mm} \text { cellular beam }\end{array}$ & 0.86 & 0.82 & 0.79 & 0.73 & 2.69 \\
\hline \multicolumn{2}{|c|}{$\begin{array}{c}\text { Increase in deflection due to loss of } \\
\text { flexural stiffness (\%) }\end{array}$} & $19 \%$ & $22 \%$ & $28 \%$ & $37 \%$ & \\
\hline \multicolumn{2}{|c|}{$\begin{array}{l}\text { Formula for increase in deflection }= \\
\qquad 0.5\left(\frac{h_{o}}{h}\right)^{1.5}\end{array}$} & $18 \%$ & $23 \%$ & $29 \%$ & $36 \%$ & \\
\hline
\end{tabular}

Parameters as in Table 1

\subsection{Equivalent rectangular opening size for bending deflection}

For a beam with circular openings, it is necessary to calculate the width of an equivalent rectangular opening in order to determine the proportionate length of the openings along the beam to be able to determine the additional pure bending deflection. This is obtained by integrating the approximate formulae (eqns (5) and (6)) for the loss of inertia around the opening.

The height of the opening at any angle, $\theta$ to the vertical is $y=h_{0} \cos \theta$; and the distance from the centre-line of the opening is $x=0.5 h_{0} \sin \theta$, as shown in Figure 3 .

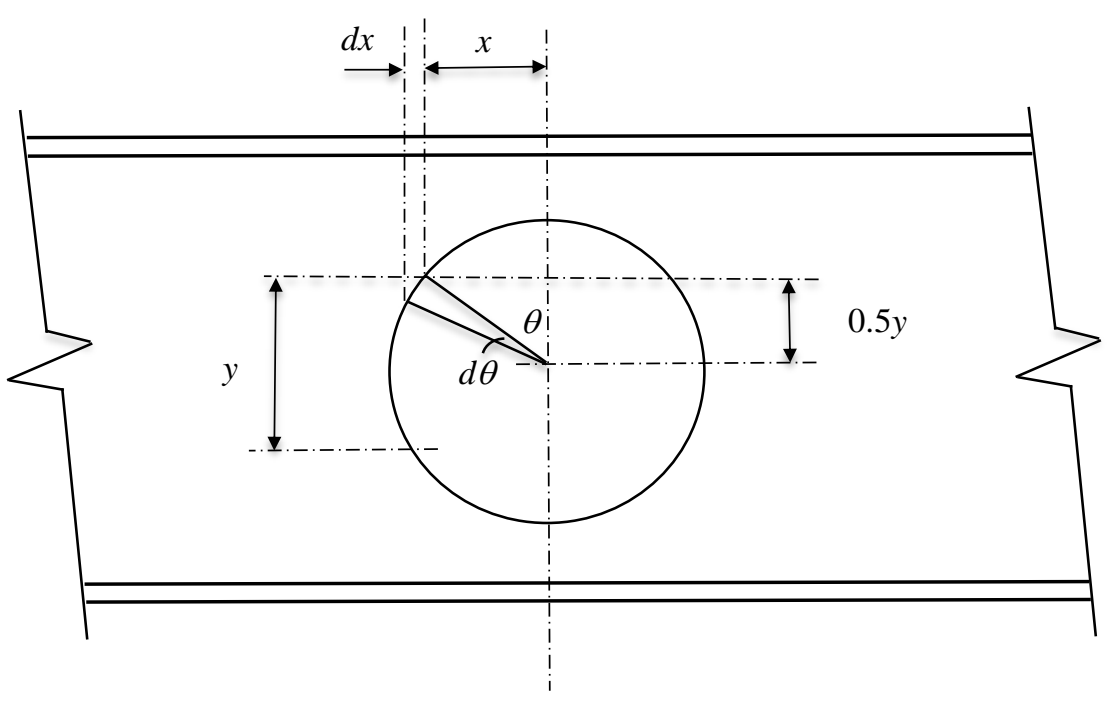

Figure 3: Integration around openings using polar coordinates

Consider the case of a composite beam with rigid shear connectors, the additional bending deflection is due to the loss in bending stiffness across the opening which is obtained by integration of $y^{1.5}$ in equations (5) and (6) with respect to the incremental width, $d x$. This leads to an effective length of the opening $\lambda_{\text {eff }}$ of height $h_{0}$ that is given by: 


$$
\lambda_{\text {eff }}=h_{\circ} \int_{\circ}^{\pi / 2} \cos ^{2.5} \theta d \theta=0.7 h_{\circ}
$$

This effective opening length concept is illustrated in Figure 4, which may be applied also to the additional shear components that are discussed later.

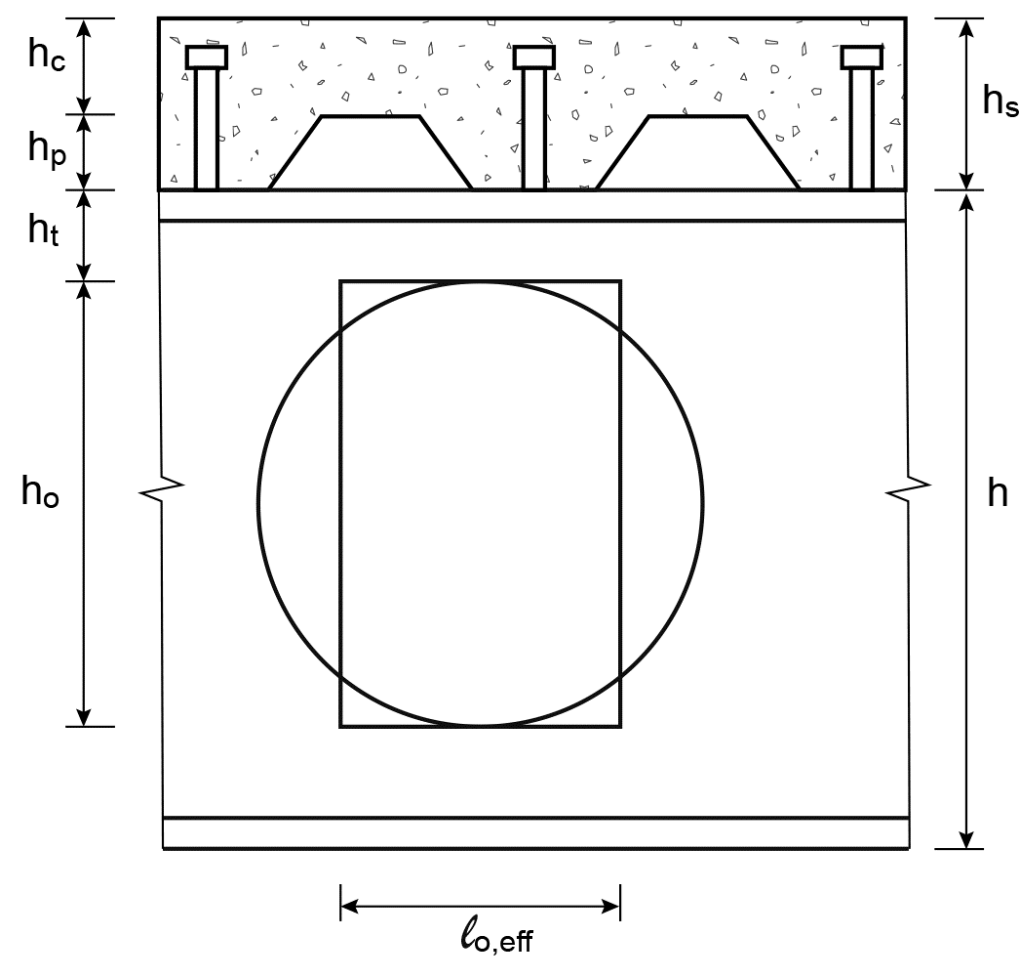

Figure 4: Effective opening length for calculation of additional bending and shear deflections

Using this effective opening length, it follows that the increase in bending deflection due to a series of circular openings in a composite beam is determined by multiplying the increase in bending deflection with a continuous opening by the term $0.7 n_{0} h_{0} / L$, which represents the proportion of the beam that is perforated. The additional bending deflection relative to the solid web composite beam for the two cases is given by:

$$
\begin{aligned}
& \mathrm{w}_{\text {add }}=\mathrm{w}_{\text {comp }} 0.28 \mathrm{n}_{\circ}\left(\frac{\mathrm{h}_{\mathrm{o}}}{\mathrm{h}}\right)^{2.5} \cdot\left(\frac{\mathrm{h}}{\mathrm{L}}\right) \quad \text { for openings cut into rolled sections (8) } \\
& \mathrm{w}_{\text {add }}=\mathrm{w}_{\text {comp }} 0.35 \mathrm{n}_{\circ}\left(\frac{\mathrm{h}_{\mathrm{o}}}{\mathrm{h}}\right)^{2.5} \cdot\left(\frac{\mathrm{h}}{\mathrm{L}}\right) \quad \text { for cut and re-welded rolled sections (9) } \\
& \text { where } \mathrm{n}_{\mathrm{o}} \text { is the number of equally spaced circular openings in the span length }
\end{aligned}
$$

For $h / h=0.7, n_{0}=L / h$, the openings leads to a $11 \%$ increase in bending deflection for a cut Isection and $14 \%$ for a cut and re-welded I-section.

As an alternative, the effective depth of the opening over the full opening length may be conservatively taken as $\mathrm{h}_{\mathrm{o}, \mathrm{eff}}=0.9 \mathrm{~h}$. 


\subsection{Effective of opening size on shear deflections}

Shear deflections also increase because of the loss of web area. For pure shear, the effective length of the opening, $\lambda_{\text {eff }}$ is given by $(2 / \pi) h_{0}=0.64 h_{0}$. For a uniformly loaded beam, the increase in mid-span deflection due to loss of shear area of a series of circular openings is determined, as follows:

$$
\mathrm{w}_{\mathrm{v}, \text { add }}=0.08 \mathrm{n}_{\circ}\left(\frac{\mathrm{h}_{\mathrm{o}}}{\mathrm{h}}\right)^{2} \frac{\mathrm{q}_{\mathrm{ser}} \mathrm{L}}{\left(1-\mathrm{h}_{\mathrm{o}} / \mathrm{h}\right) \mathrm{Gt}} \mathrm{w}
$$

where $q_{\text {ser }}$ is the line load in service conditions acting on the beam per unit length

$t_{\mathrm{w}}$ is the web thickness

and $G$ is the shear modulus of steel

A further component of shear deflection arises from Vierendeel bending across the opening. Over the range of rolled IPE steel sections, the inertia of a Tee section of depth, $h_{t}$ above the centre of the opening is given with reasonable accuracy by $I_{T e e}=h_{t}{ }^{3} t_{w} / 4.5=\left(h-h_{0}\right)^{3} t_{w} / 36$. Therefore, for a symmetric rolled section, the Vierendeel bending deflection across a single rectangular opening of length, $\lambda_{\text {eff, Vier }}$ is:

$$
w_{\text {Vier,ect }}=1.5\left(\frac{\lambda_{\text {eff,Vier }}}{\mathrm{h}-\mathrm{h}_{\mathrm{o}}}\right)^{3}\left(\frac{\mathrm{V}_{\mathrm{Ed}, \mathrm{ser}}}{\mathrm{Et}_{\mathrm{w}}}\right)
$$

where $V_{E d, s e r}$ is the vertical shear force at the opening in service conditions

The deflection across a circular opening due to Vierendeel bending may be determined by integration of the bending strain around the circle. The inertia of the Tee section at any position around the opening is approximately given by: $I_{\text {Tee }}=\left(h-h_{0} \cos \theta\right)^{3} t_{w} / 36$, where $\theta$ is the angle to the vertical around the opening. Using this inertia, and the bending moment acting on the Tee at the horizontal position $x=0.5 h_{0} \sin \theta$, the shear deflection across the opening due to Vierendee/ bending is given by the following integral:

$$
\mathrm{w}_{\text {Vier }}=4.5\left(\frac{\mathrm{V}_{\mathrm{Ed}, \mathrm{ser}}}{\mathrm{Et}_{\mathrm{w}}}\right) \int_{0}^{\pi / 2} \frac{\sin ^{2} \theta \cdot \cos \theta}{\left(\mathrm{h} / \mathrm{h}_{\mathrm{o}}-\cos \theta\right)^{3}} \mathrm{~d} \theta
$$

This equation may be integrated numerically for different opening sizes. An approximate equation for the Vierendeel bending deflection, $w_{\text {Vier }}$, based on the above integral is given by:

$$
w_{\text {Vier }}=0.75\left(\frac{\mathrm{h}_{\mathrm{o}}}{\mathrm{h}-\mathrm{h}_{\mathrm{o}}}\right)^{2}\left(\frac{\mathrm{V}_{\mathrm{Ed}, \mathrm{ser}}}{\mathrm{Et}_{\mathrm{w}}}\right)
$$

Equation (13) corresponds to an effective opening length for Vierendeel bending of:

$$
\lambda_{\text {eff,Vier }}=0.8 h_{\circ}\left(\frac{h-h_{\circ}}{h_{\circ}}\right)^{0.33}
$$

It follows that for $h_{0} / h=0.7 ; \lambda_{\text {eff,Vier }}=0.6 h_{0}$, which is less than for pure bending and shear.

The effect of local composite action at the circular openings reduces the Vierendeel component of shear deflection significantly. Based on FE modelling, it is shown that the Vierendeel bending stiffness of the composite top Tee is increased by a factor of 3 to 5 , depending on the relative depth of the slab and the Tee. Therefore, the average bending 
stiffness of the top and bottom Tees is 2 to 3 times that of the steel Tee. For design purposes, a factor of $\times 0.5$ may be applied conservatively to equation (13) to obtain the Vierendeel deflection of the equivalent composite beam.

Therefore, for a composite cellular beam with $\mathrm{n}_{\mathrm{o}}$ circular openings subject to uniform loading, the additional mid -span deflection due to Vierendee/ bending is given approximately by:

$$
w_{\text {Vier,add }}=0.05 \mathrm{n}_{\mathrm{o}}\left(\frac{\mathrm{h}_{\mathrm{o}}}{\mathrm{h}-\mathrm{h}_{\mathrm{o}}}\right)^{2}\left(\frac{\mathrm{q}_{\text {ser }} \mathrm{L}}{\mathrm{Et}_{\mathrm{w}}}\right)
$$

\subsection{Effect of web-post bending on shear deflections}

Web-post bending occurs due to horizontal shear force acting at the centre-line of the opening. The inertia of the web-post at any height above the centre-line of the circular opening is given by: $I_{W P}=\left(s-h_{0} \cos \alpha\right)^{3} t_{w} / 12$. Therefore, the horizontal deflection across the full height of the web-post due to horizontal shear is given by the following integral:

$$
\mathrm{w}_{\mathrm{wpb}, \mathrm{h}}=\left(\frac{\mathrm{V}_{\mathrm{h}, \mathrm{Ed}}}{\mathrm{Et}_{\mathrm{w}}}\right) \int_{0}^{\pi / 2} \frac{\sin ^{2} \alpha \cdot \cos \alpha}{\left(\mathrm{s} / \mathrm{h}_{\mathrm{o}}-\cos \alpha\right)^{3}} d \alpha
$$

where $\alpha$ is the angle to the horizontal around the circle

$s$ is the centre to centre spacing of the openings

$V_{h, E d}$ is the horizontal shear force in the web-post corresponding to a vertical shear force of $V_{E d, s e r}$.

For a composite beam with full shear connection, the horizontal shear force in the web-post is determined from the equilibrium of force illustrated in Figure 5. For full shear connection, the web-post shear force is related to the vertical shear force according to: $V_{h, E d}=V_{E d, s e r}(s /$ $\left.\left(h+h_{s, \text { eff }}\right)\right)$, where $h_{s, \text { eff }}$ is the effective depth of the slab to the centre of the compression force. This may be taken as approximately, $h_{s, \text { eff }}=0.8 h_{s}$, where $h_{s}$ is the slab depth. In the normal range of application, $h_{s}=0.2$ to $0.25 \mathrm{~h}$, and so the horizontal shear force is given approximately by: $\mathrm{V}_{\mathrm{h}, \mathrm{Ed}}=0.85 \mathrm{~V}_{\mathrm{Ed}, \mathrm{ser}}(\mathrm{s} / \mathrm{h})$. From compatibility of deflections, the vertical displacement between the centre of adjacent openings due to vertical shear is multiplied by $(\mathrm{s} / \mathrm{h})$.

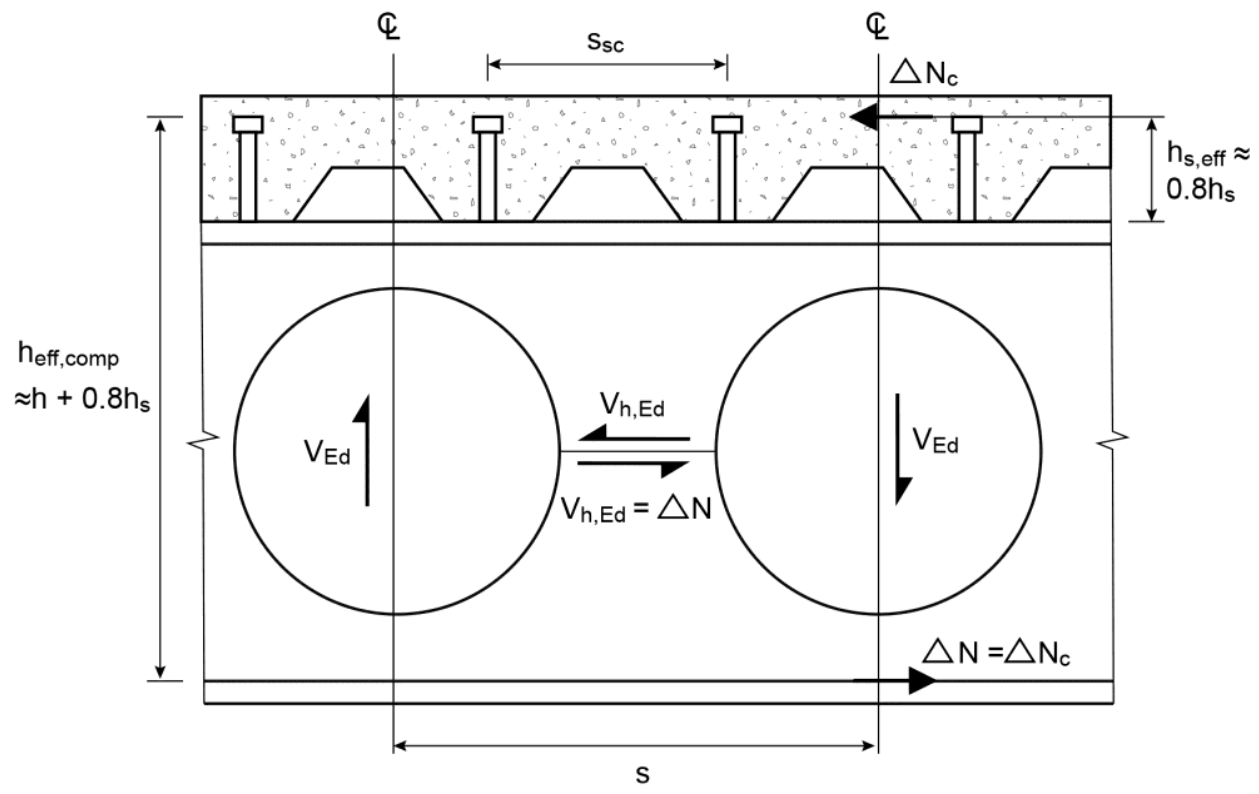

Figure 5: Equilibrium of forces between openings in a composite beam 
Equation (16) may be integrated numerically for different web -post widths. Based on the above integrations, an approximate equation for the vertical shear deflection, $\mathbf{w}_{\mathrm{wpb}}$ between the centre of adjacent openings due web-post bending is:

$$
w_{\text {wpb }}=0.2\left(\frac{\mathrm{h}_{\mathrm{o}}}{\mathrm{s}-\mathrm{h}_{\mathrm{o}}}\right)^{2}\left(\frac{\mathrm{s}}{\mathrm{h}}\right)^{2}\left(\frac{\mathrm{V}_{\mathrm{Ed}, \mathrm{ser}}}{\mathrm{Et}_{\mathrm{w}}}\right)
$$

This corresponds to an effective opening height for bending of the web-post over its minimum width that is illustrated in Figure 6 and is given by:

$$
\mathrm{h}_{\mathrm{o}, \text { eff }}=0.63 \mathrm{~h}_{\mathrm{o}}\left(\frac{\mathrm{s}-\mathrm{h}_{\mathrm{o}}}{\mathrm{h}_{\mathrm{o}}}\right)^{0.33}
$$

For $s=1.5 h_{0}$ and $h_{0}=0.7 h$, the effective opening height, $h_{o, \text { eff }}=0.5 h_{0}$ for web-post bending.

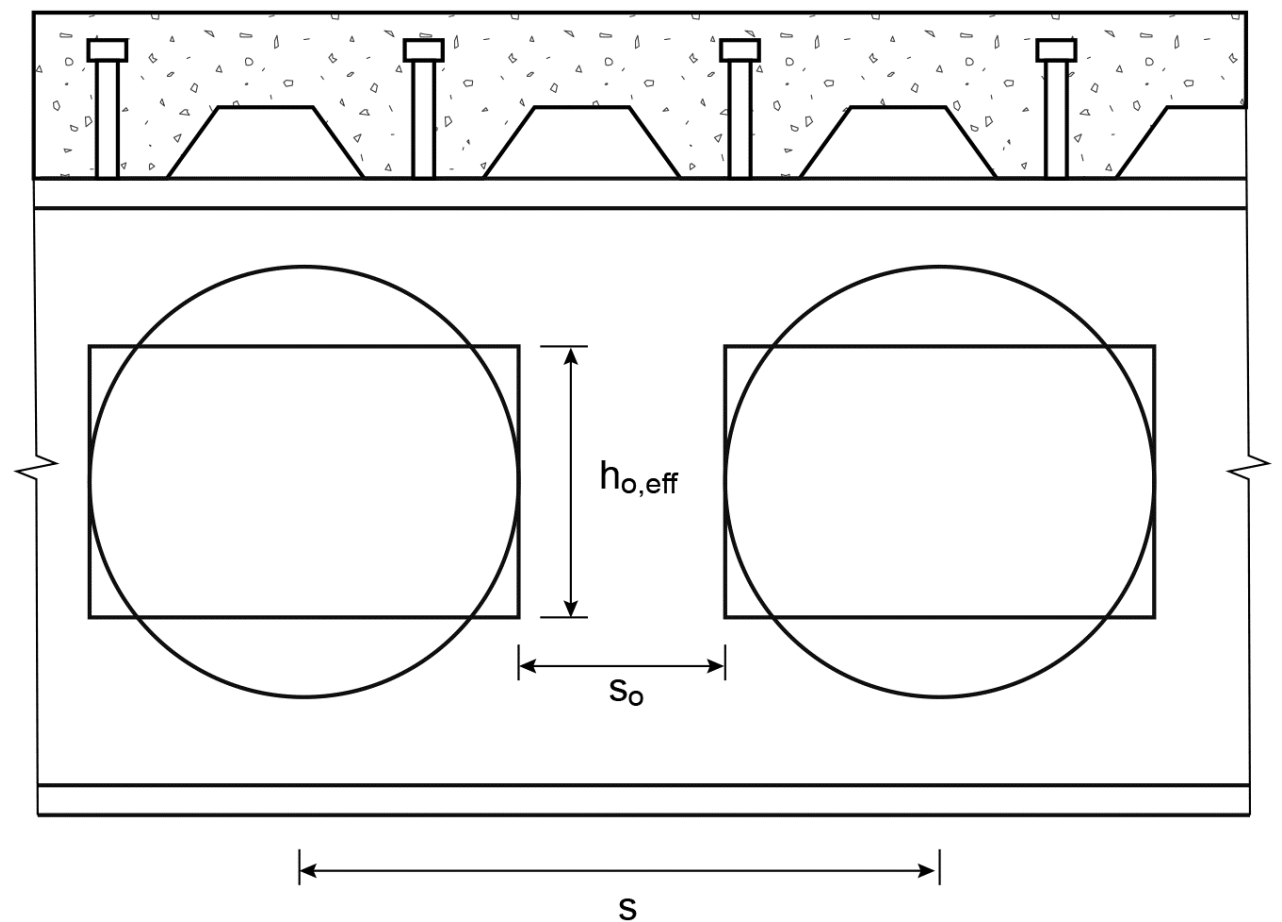

Figure 6: Effective opening height for calculation of additional shear deflections due to web -post bending

From equation (17), it follows that for uniformly loaded beam with a series of circular openings, the additional mid-span deflection due to web-post bending is given by:

$$
w_{\text {wpb add }}=0.025 \mathrm{n}_{\circ}\left(\frac{\mathrm{h}_{\mathrm{o}}}{\mathrm{s}-\mathrm{h}_{\mathrm{o}}}\right)^{2}\left(\frac{\mathrm{s}}{\mathrm{h}}\right)^{2}\left(\frac{\mathrm{q}_{\mathrm{ser}} \mathrm{L}}{\mathrm{Et}_{\mathrm{w}}}\right)
$$

As an alternative further simplified approach, the effective opening length may taken for all deflection calculations as: $\lambda_{\text {eff }}=0.7 h_{0}$, as illustrated in Figure 4, and therefore the effective web-post width over its full height becomes: $\left(\mathrm{s}-0.7 \mathrm{~h}_{\mathrm{o}}\right)$. For web-post bending over the full height of the opening, allowing for $\mathrm{V}_{\mathrm{h}, \mathrm{Ed}}=0.85 \mathrm{~V}_{\mathrm{Ed}, \mathrm{ser}}(\mathrm{s} / \mathrm{h})$, the additional shear deflection is now given by:

$$
w_{\text {wpb,add }}=0.1 \mathrm{n}_{\circ}\left(\frac{\mathrm{h}_{\circ}}{\mathrm{s}-0.7 \mathrm{~h}_{\mathrm{o}}}\right)^{3}\left(\frac{\mathrm{s}}{\mathrm{h}}\right)^{2}\left(\frac{\mathrm{q}_{\mathrm{ser}} \mathrm{L}}{\mathrm{Et}_{\mathrm{w}}}\right)
$$

Equation (20) is shown to be conservative in comparison to Equation (19) over the normal range of $\mathrm{s} / \mathrm{h}_{\mathrm{o}}$ ratios between 1.3 and 1.7 . 


\subsection{Additional deflections due to combination of shear and bending}

The total additional shear deflection, $\mathrm{w}_{\mathrm{v}, \text { add }}$ due to a series of circular openings in a uniformly loaded composite beam is given by combining equations (10), (15) and (19), as follows:

$$
\frac{w_{v, \text { add }}}{w_{\text {comp }}}=20 \mathrm{n}_{\circ}\left(\frac{\mathrm{h}_{\mathrm{o}}}{\mathrm{h}-\mathrm{h}_{\mathrm{o}}}\right)^{2}\left(1-0.8 \frac{\mathrm{h}_{\mathrm{o}}}{\mathrm{h}}+0.1\left(\frac{\mathrm{h}-\mathrm{h}_{\mathrm{o}}}{\mathrm{s}-\mathrm{h}_{\mathrm{o}}}\right)^{2}\left(\frac{\mathrm{s}}{\mathrm{h}}\right)^{2}\right)\left(\frac{\mathrm{I}_{\text {comp }}}{\mathrm{h}^{3} \mathrm{t}}\right)\left(\frac{\mathrm{h}}{\mathrm{L}}\right)^{3}
$$

Where $I_{\text {comp }}$ is the inertia of the equivalent composite section with a solid web.

It is found that for composite beams using rolled steel sections, the bending stiffness of the composite section falls into a relatively narrow range. As a reasonable approximation for rolled sections in which the slab depth is in the range of 20 to $25 \%$ of the depth of the steel beam, the composite inertia is given by:

$$
\begin{array}{ll}
\mathrm{I}_{\text {comp }}=1.1 \mathrm{~h}^{3} \mathrm{t}_{\mathrm{w}} & \text { for composite I-beams using rolled sections } \\
\mathrm{I}_{\text {comp }}=0.9 \mathrm{~h}^{3} \mathrm{t}_{\mathrm{w}} & \text { for composite beams formed by cutting and re-welding I-sections }
\end{array}
$$

This leads to the following formulae for the additional mid-span deflection of composite beams with multiple circular openings for beams subject to uniform loading:

1. Rolled I beams with cut openings:

$$
\frac{w_{\text {add }}}{w_{\text {comp }}}=0.28 \mathrm{n}_{\mathrm{\circ}}\left(\frac{\mathrm{h}_{\mathrm{o}}}{\mathrm{h}}\right)^{2.5} \cdot\left(\frac{\mathrm{h}}{\mathrm{L}}\right)+22 \mathrm{n}_{\mathrm{\circ}}\left(\frac{\mathrm{h}_{\mathrm{o}}}{\mathrm{h}-\mathrm{h}_{\mathrm{o}}}\right)^{2}\left(1-0.8 \frac{\mathrm{h}_{\mathrm{o}}}{\mathrm{h}}+0.1\left(\frac{\mathrm{h}-\mathrm{h}_{\mathrm{o}}}{\mathrm{s}-\mathrm{h}_{\mathrm{o}}}\right)^{2}\left(\frac{\mathrm{s}}{\mathrm{h}}\right)^{2}\right)\left(\frac{\mathrm{h}}{\mathrm{L}}\right)^{3}
$$

2. Cellular beams formed by cutting and re-welding I beams:

$$
\frac{\text { wadd }}{\text { w comp }}=0.35 \mathrm{n}_{\circ}\left(\frac{\mathrm{h}_{\mathrm{o}}}{\mathrm{h}}\right)^{2.5} \cdot\left(\frac{\mathrm{h}}{\mathrm{L}}\right)+18 \mathrm{n}_{\circ}\left(\frac{\mathrm{h}_{\mathrm{o}}}{\mathrm{h}-\mathrm{h}_{\mathrm{o}}}\right)^{2}\left(1-0.8 \frac{\mathrm{h}_{\mathrm{o}}}{\mathrm{h}}+0.1\left(\frac{\mathrm{h}-\mathrm{h}_{\mathrm{o}}}{\mathrm{s}-\mathrm{h}_{\mathrm{o}}}\right)^{2}\left(\frac{\mathrm{s}}{\mathrm{h}}\right)^{2}\right)\left(\frac{\mathrm{h}}{\mathrm{L}}\right)^{3}
$$

The difference between these formulae is due to the relative area of the flanges to the web of the two types of section. The formulae show that the additional bending deflection is higher for cellular beams but the additional shear deflection is lower than for beams with cut openings. The ratio of the shear to bending terms is dependent on $(\mathrm{L} / \mathrm{h})^{2}$ and so the additional shear deflection will dominate for span: depth ratios less than about 15 . The combination of the component deflections for two typical long span composite beams formed by cutting openings in IPE 500 sections or by cutting and re-welding IPE 500 sections to form a deeper section is presented in Table 3. Representative span: depth ratios are used for the two cases.

A study of the effect of a wide range of circular opening sizes on the deflection of composite beams leads to the following simplified formulae for the additional mid-span deflection due to a series of circular openings in a uniformly loaded beam:

$$
\frac{w_{\text {add }}}{w_{b}}=3 n_{o}\left(\frac{h_{o}}{h}\right)^{3}\left(\frac{h}{L}\right)^{1.5} \quad \text { for } \mathrm{s}>1.5 \mathrm{~h}_{\circ}
$$




$$
\frac{w_{a d d}}{w_{b}}=1.5 n_{o}\left(\frac{h_{o}}{h}\right)^{3}\left(\frac{h_{o}}{s-h_{o}}\right)\left(\frac{h}{L}\right)^{1.5} \text { for } \mathrm{s}<1.5 \mathrm{~h}_{\circ}
$$

This formula is accurate for opening sizes up to $h_{0} / h \leq 0.75$, and beam span: depth ratio $\geq 18$, which covers the practical range of application of composite beams. It is more conservative for rolled sections with cut openings than for cellular beams with cut-and re-welded sections. The results of these simplified equations are confirmed by finite element modelling and by the fullscale cellular beam test described below.

Table 3: Deflections for typical long span beams using IPE 500 sections for both cut circular openings and cut and re-welded cellular beams obtained from equations (24) and (25)

\begin{tabular}{|c|c|c|c|c|c|c|c|c|}
\hline \multirow{2}{*}{$\begin{array}{l}\text { Span and } \\
\text { beam } \\
\text { Size }\end{array}$} & \multirow[b]{2}{*}{$\begin{array}{l}\text { Bending } \\
\text { deflection } \\
\text { of solid } \\
\text { web } \\
\text { beam }\end{array}$} & \multirow{2}{*}{$\begin{array}{l}\text { Ratio } \\
h_{0} / h\end{array}$} & \multicolumn{5}{|c|}{ Additional deflection ( $\mathrm{mm}$ ) due to openings: } & \multirow{2}{*}{$\begin{array}{l}\text { Approximate } \\
\text { equations } \\
\text { (24) and (25) } \\
\text { for } \\
\mathrm{W}_{\text {add }} / \mathrm{w}_{\text {comp }}=\end{array}$} \\
\hline & & & $\begin{array}{l}\text { Pure } \\
\text { bending }\end{array}$ & $\begin{array}{l}\text { Shear \& } \\
\text { Vierendeel } \\
\text { bending }\end{array}$ & $\begin{array}{l}\text { Web- } \\
\text { post } \\
\text { bending }\end{array}$ & $\begin{array}{l}\text { Total } \\
\text { Add. } \\
\text { Defln }\end{array}$ & $\begin{array}{l}\mathbf{W}_{\text {add }} / \\
\mathbf{W}_{\text {comp }}\end{array}$ & \\
\hline \multirow{4}{*}{$\begin{array}{l}\text { Span } 12 \mathrm{~m} \\
\text { IPE } 500 \text { with } \\
\text { cut openings }\end{array}$} & \multirow{4}{*}{$\begin{array}{l}\mathrm{W}_{\text {comp }}= \\
17.0 \mathrm{~mm}\end{array}$} & 0.8 & 2.7 & 3.7 & 1.1 & 7.6 & 0.45 & $0.63 / 0.50$ \\
\hline & & 0.7 & 1.9 & 1.6 & 0.6 & 4.1 & 0.24 & $0.35 / 0.28$ \\
\hline & & 0.6 & 1.3 & 0.8 & 0.3 & 2.4 & 0.14 & 0.13 \\
\hline & & 0.5 & 0.7 & 0.3 & 0.1 & 1.1 & 0.06 & 0.08 \\
\hline \multirow{4}{*}{$\begin{array}{l}\text { Span } 15 \mathrm{~m} \\
\text { IPE } 500 \text { in } \\
750 \mathrm{~mm} \text { deep } \\
\text { cut and re- } \\
\text { welded section }\end{array}$} & \multirow{4}{*}{$\begin{array}{l}\mathrm{W}_{\text {comp }} \\
14.9 \mathrm{~mm}\end{array}=$} & 0.8 & 3.0 & 3.7 & 1.2 & 7.9 & 0.53 & $0.86 / 0.69$ \\
\hline & & 0.7 & 2.1 & 1.6 & 0.5 & 4.2 & 0.28 & $0.38 / 0.30$ \\
\hline & & 0.6 & 1.4 & 0.8 & 0.2 & 2.4 & 0.16 & 0.14 \\
\hline & & 0.5 & 0.9 & 0.3 & 0.0 & 1.2 & 0.08 & 0.08 \\
\hline
\end{tabular}

Data for serviceability load: $\mathrm{q}_{\mathrm{ser}}=15 \mathrm{kN} / \mathrm{m}$ and $\mathrm{n}_{\mathrm{o}}=\mathrm{L} / \mathrm{h}$ and for slab depth of $130 \mathrm{~mm}$ with $60 \mathrm{~mm}$ deep deck profile

\section{Finite Element Study of Additional Deflection of Cellular Beams}

The research in the project DISCCo was divided into two series of analyses: a limited series of on symmetric composite beams using the finite element program, ANSYS and a more comprehensive series on asymmetric composite cellular beams using the finite element program, Abaqus. The analyses were also used to compare the results of both programs and were calibrated against the $15.3 \mathrm{~m}$ span composite cellular beam test described later. It is not the purpose of this paper to explain the models in detail but the following information is presented on the models:

The $19 \mathrm{~mm}$ diameter shear connectors were configured as tri-linear 'springs' placed singly per deck rib at $300 \mathrm{~mm}$ spacing. The two models are shown diagrammatically in Figure 7 . In the ANSYS model, the spring was connected to the base of the rib and in the Abaqus model, the spring was located at the mid-height of the rib and then to the solid part of the slab. Based on push-out tests, the maximum shear resistance of the shear connectors was taken as $70 \mathrm{kN}$ and the elastic stiffness was $70 \mathrm{kN} / \mathrm{mm}$. The plastic resistance of the shear connectors was continued to a slip of $6 \mathrm{~mm}$ and was assumed to decline linearly by $10 \%$ to a slip of $10 \mathrm{~mm}$, as shown in Figure 8. 


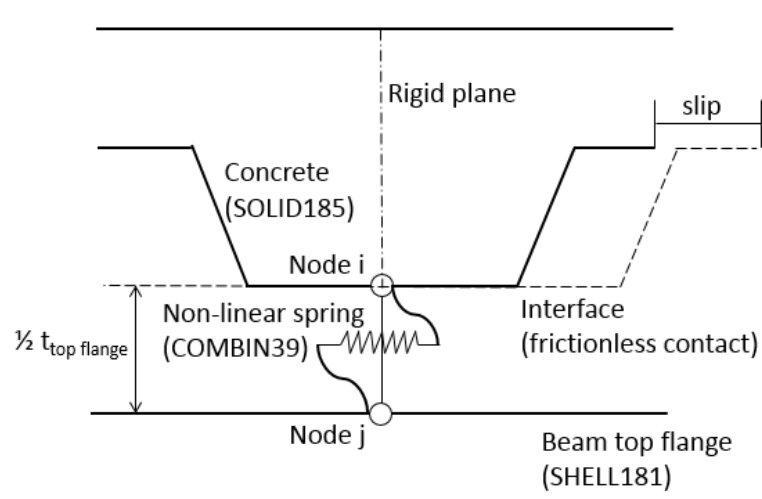

(a) ANSYS model
Rigid plane tied to slabs (2X)

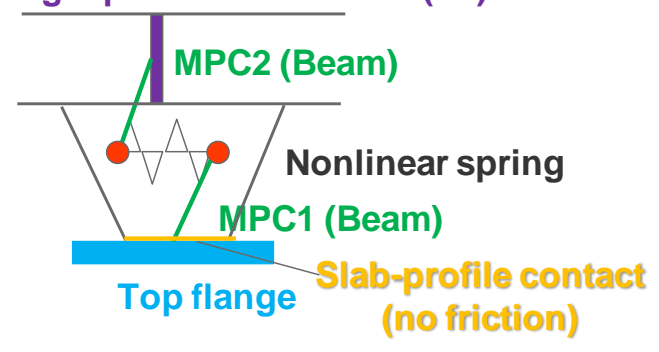

(b) Abaqus model

Figure 7: Modelling of shear connectors in finite element analyses

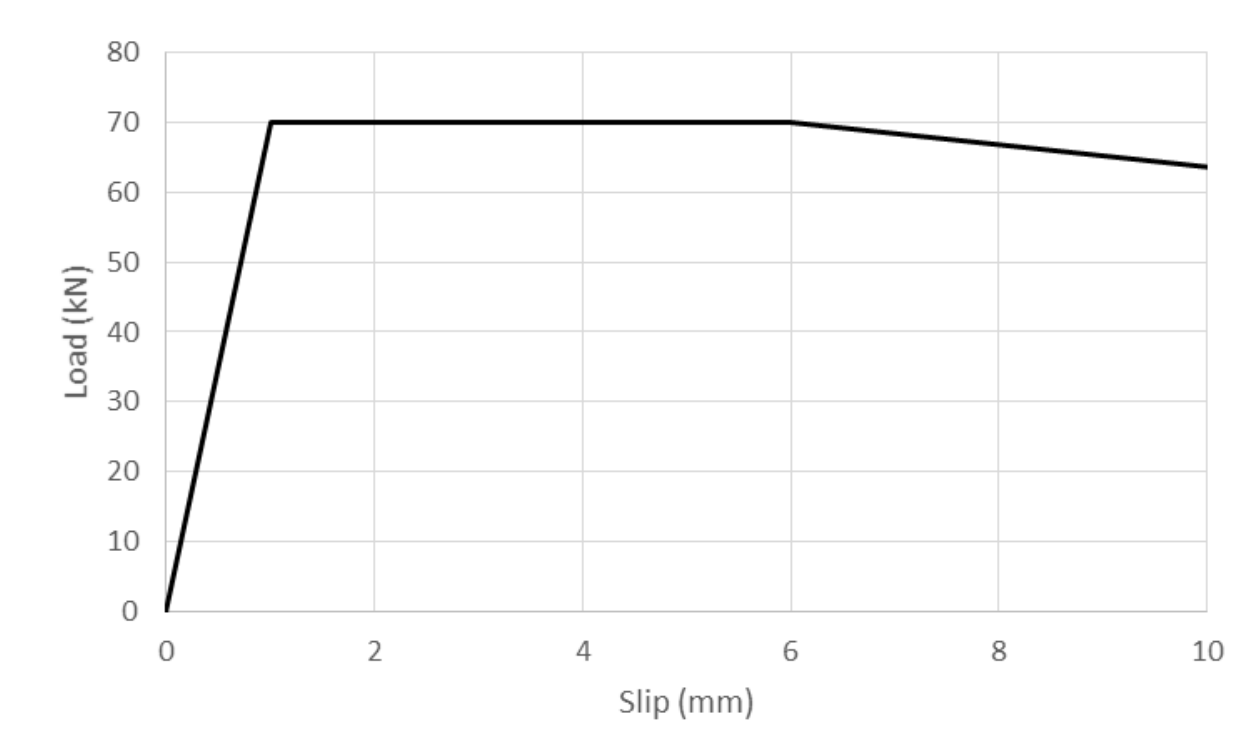

Figure 8: Tri-linear relationship for shear connectors used in the FE models

The models were also adapted to analyse the case of effectively 'rigid' shear connectors by using a notional shear stiffness of $1000 \mathrm{kN} / \mathrm{mm}$. The main interest in this paper was to identify the contribution of the openings to the additional shear and bending deflections, as also influenced by partial shear connection.

The ANSYS models used a tri-linear relationship for concrete, and in Abaqus, the concrete material behaviour was defined in according to the parabolic stress strain curve in EN 1992-11 (16). The difference with respect to the tri-linear analysis in ANSYS is presented in Figure 9 and was not felt to be significant. The Abaqus models also used the concrete damaged plasticity model for the composite slab although this was not required for the results at serviceability load levels. The dilation angle was taken as $40^{\circ}$, while default values were assumed for all other plasticity parameters. In Figure 9, the elastic modulus is $22.5 \mathrm{kN} / \mathrm{mm}^{2}$, which is representative of that used to calculate deflections due to imposed loading, where the load duration is equivalent to one third being short term and two thirds long term. 


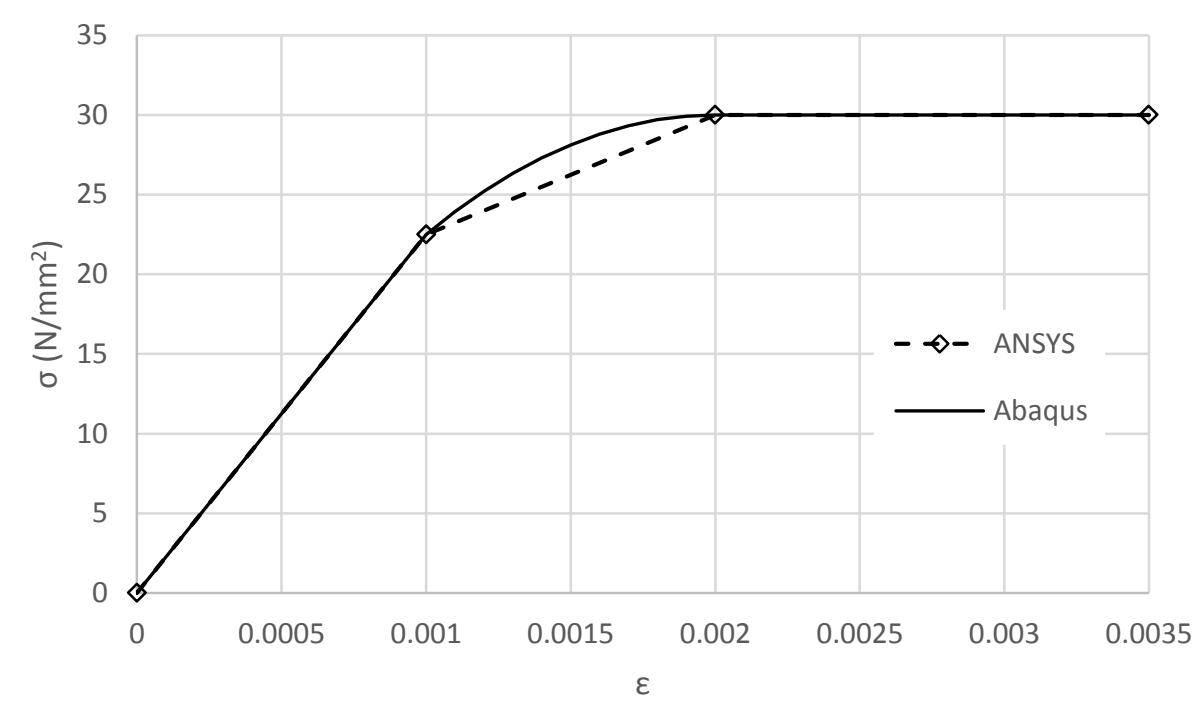

Figure 9: Tri-linear and parabolic stress-strain relationships for concrete used in the FE models

The results of the two series of analyses are presented as follows:

\subsection{Analysis of symmetric cellular beam sections}

In the ANSYS models, symmetric composite beams using IPE 400, 500 and 600 sections with cut openings of $67 \%$ to $75 \%$ of the depth of the beam were analysed. The uniformly loaded beams had a span: depth ratio of 22.5 to 25 , which is typical of the practical range. The slab depth was $150 \mathrm{~mm}$ and the deck profile height was $80 \mathrm{~mm}$ and the degree of shear connection was about $35 \%$ in all the models based on single shear connectors per deck rib.

The load used to determine the deflections was taken as $6 \mathrm{kN} / \mathrm{m}^{2}$ acting over the slab widths given in Table 4 and using this load, the ratio of the serviceability moment due to the imposed load to the bending resistance of the composite beam for partial shear connection was in the range of $27 \%$ to $47 \%$. The FE models were repeated for equivalent solid web beams in order to determine the effect of the openings for the same shear connector stiffness.

Table 4: Data of the composite beams with cut openings used in the ANSYS models

\begin{tabular}{|c|c|c|c|c|c|c|c|c|}
\hline \multirow{2}{*}{$\begin{array}{c}\text { Beam } \\
\text { span }\end{array}$} & $\begin{array}{c}\text { Beam } \\
\text { Size } \\
\text { (S355) }\end{array}$ & $\begin{array}{c}\text { Opening } \\
\text { diameter, } \\
\mathrm{h}_{\circ}\end{array}$ & $\mathrm{n}_{\circ}$ & $\begin{array}{c}\text { Slab } \\
\text { width }\end{array}$ & $\eta$ & \multicolumn{2}{|c|}{$\begin{array}{c}\text { Calculated composite inertia } \\
\text { of solid web beam, } \mathrm{mm}^{4}\end{array}$} & $\begin{array}{c}\text { Composite inertia } \\
\text { at opening, } \mathrm{mm}^{4}\end{array}$ \\
\cline { 5 - 9 } & & & & & \multicolumn{2}{|c|}{$\begin{array}{c}\text { Rigid shear } \\
\text { connectors }\end{array}$} & \multicolumn{2}{|c|}{$\begin{array}{c}\text { Flexible shear connectors-using } \\
\text { eqn(2) }\end{array}$} \\
\hline $9 \mathrm{~m}$ & IPE 400 & $300 \mathrm{~mm}$ & 15 & $2.25 \mathrm{~m}$ & $35 \%$ & $754 \times 10^{6}$ & $560 \times 10^{6}$ & $485 \times 10^{6}$ \\
\hline $12 \mathrm{~m}$ & IPE 500 & $350 \mathrm{~mm}$ & 17 & $3.0 \mathrm{~m}$ & $34 \%$ & $1443 \times 10^{6}$ & $1167 \times 10^{6}$ & $1008 \times 10^{6}$ \\
\hline $15 \mathrm{~m}$ & IPE 600 & $400 \mathrm{~mm}$ & 21 & $3.75 \mathrm{~m}$ & $33 \%$ & $2543 \times 10^{6}$ & $2091 \times 10^{6}$ & $1815 \times 10^{6}$ \\
\hline
\end{tabular}

Loading $=6 \mathrm{kN} / \mathrm{m}^{2}$ : Slab depth $=150 \mathrm{~mm}$ : Deck depth $=80 \mathrm{~mm}$; Shear connector stiffness, $\mathrm{k}_{\mathrm{sc}}=70 \mathrm{kN} / \mathrm{mm}$ at $300 \mathrm{~mm}$ spacing. $\mathrm{n}_{\mathrm{o}}=$ number of openings in the span $\eta=$ degree of shear connection

The results were compared to the simplified formula in equation (23) and are presented in Table 5 showing also the term due to the additional shear deflection caused by the openings. Although the pure shear deflection of the solid web beam is small, it is nevertheless important when comparing the differences between the results. It is shown that the theoretical method with this adjustment for shear displacement agrees well with the FE results, as also observed later in the $15 \mathrm{~m}$ span cellular beam test. The increase in deflection due to the openings 
ranged from 15 to $18 \%$ of that of the solid web beam for the case of flexible shear connectors, which was 4 to $7 \%$ less than for rigid shear connectors. However, the absolute increase in deflection due to the openings was similar for rigid and flexible shear connectors.

Table 5: Comparison of deflections $(\mathrm{mm})$ of solid web beams and cellular beams from ANSYS, theory for rigid and flexible shear connectors

(a) Rigid shear connectors

\begin{tabular}{|c|c|c|c|c|c|c|c|c|c|}
\hline \multirow[b]{3}{*}{$\begin{array}{c}\text { Beam } \\
\text { Span } \\
\text { (m) }\end{array}$} & \multicolumn{4}{|c|}{ Deflection of solid web beam } & \multicolumn{5}{|c|}{ Deflection of beam with circular openings } \\
\hline & \multirow[b]{2}{*}{$\begin{array}{l}\text { Defln. } \\
\text { from } \\
\text { FEA }\end{array}$} & \multicolumn{3}{|c|}{$\begin{array}{c}\text { Theoretical deflection of } \\
\text { composite beam }(\mathrm{mm})\end{array}$} & \multirow[b]{2}{*}{$\begin{array}{l}\text { Defln. } \\
\text { from } \\
\text { FEA }\end{array}$} & \multicolumn{3}{|c|}{$\begin{array}{l}\text { Deflection of composite beam } \\
\text { (mm) using equation (23) }\end{array}$} & \multirow{2}{*}{$\begin{array}{l}\text { Add. defln. } \\
\text { due to } \\
\text { openings } \\
\text { based on } \\
\text { FEA, wadd }\end{array}$} \\
\hline & & Bending & $\begin{array}{l}\text { Pure } \\
\text { shear }\end{array}$ & Total & & Bending & $\begin{array}{l}\text { Shear due } \\
\text { to openings } \\
\text { \& solid web }\end{array}$ & Total & \\
\hline 9 & 8.9 & 7.9 & 0.5 & 8.4 & 11.1 & 9.2 & 1.7 & 10.9 & $\begin{array}{c}2.2 \mathrm{~mm} \\
(25 \%)\end{array}$ \\
\hline 12 & 18.9 & 17.4 & 0.8 & 18.2 & 22.8 & 19.8 & 2.3 & 22.1 & $\begin{array}{c}3.9 \mathrm{~mm} \\
(20 \%)\end{array}$ \\
\hline 15 & 32.5 & 30.0 & 1.1 & 31.1 & 38.6 & 33.8 & 2.9 & 36.7 & $\begin{array}{c}6.1 \mathrm{~mm} \\
(19 \%)\end{array}$ \\
\hline
\end{tabular}

(b) Flexible shear connectors (stiffness of shear connector, $\mathrm{k}_{\mathrm{sc}}=70 \mathrm{kN} / \mathrm{mm}$ )

\begin{tabular}{|c|c|c|c|c|c|c|c|c|c|}
\hline \multirow[b]{3}{*}{$\begin{array}{l}\text { Beam } \\
\text { Span } \\
\text { (m) }\end{array}$} & \multicolumn{4}{|c|}{ Deflection of solid web beam } & \multicolumn{5}{|c|}{ Deflection of beam with circular openings } \\
\hline & \multirow[b]{2}{*}{$\begin{array}{l}\text { Defln. } \\
\text { from } \\
\text { FEA }\end{array}$} & \multicolumn{3}{|c|}{$\begin{array}{l}\text { Theoretical deflection of } \\
\text { composite beam }(\mathrm{mm})\end{array}$} & \multirow[b]{2}{*}{$\begin{array}{l}\text { Defln. } \\
\text { from } \\
\text { FEA }\end{array}$} & \multicolumn{3}{|c|}{$\begin{array}{l}\text { Deflection of composite beam } \\
\text { (mm) using equation (23) }\end{array}$} & \multirow{2}{*}{$\begin{array}{l}\text { Add. defln. } \\
\text { due to } \\
\text { openings } \\
\text { based on } \\
\text { FEA, wadd }\end{array}$} \\
\hline & & Bending & $\begin{array}{l}\text { Pure } \\
\text { shear }\end{array}$ & Total & & Bending & $\begin{array}{l}\text { Shear due } \\
\text { to openings } \\
\text { \& solid web }\end{array}$ & Total & \\
\hline 9 & 11.1 & 10.1 & 0.5 & 10.6 & 13.1 & 11.8 & 2.1 & 13.9 & $\begin{array}{c}2.0 \mathrm{~mm} \\
(18 \%)\end{array}$ \\
\hline 12 & 22.5 & 21.0 & 0.8 & 21.8 & 26.2 & 24.0 & 2.6 & 26.6 & $\begin{array}{c}3.7 \mathrm{~mm} \\
(16 \%)\end{array}$ \\
\hline 15 & 37.5 & 35.1 & 1.1 & 36.2 & 43.2 & 39.5 & 3.2 & 42.7 & $\begin{array}{c}5.7 \mathrm{~mm} \\
(15 \%)\end{array}$ \\
\hline
\end{tabular}

\subsection{Analysis of asymmetric cellular beam sections}

The Abaqus finite element analyses used cellular beams formed by cutting and re-welding IPE and $\mathrm{HE}$ sections and had a range of asymmetries in flange areas from 1.2 to 2.4. The combination of Tee sections is presented in Tables 6 and 7, and the opening diameters were varied from $55 \%$ to $77 \%$ of the beam depth within the same section size. The beam span to depth ratios were covered a relatively wide range from 18 to 31 . The additional deflections for the longer span: depth ratios are due mainly to the reduced bending stiffness of the cellular beam, whereas those with shorter span: depth ratios include a larger contribution of the effects of shear.

Two composite slab configurations were analysed in this series to cover the sensible range of application. The first cases used single $19 \mathrm{~mm}$ diameter shear connectors in a $120 \mathrm{~mm}$ deep slab with a $56 \mathrm{~mm}$ deep deck profile and $207 \mathrm{~mm}$ rib pacing in which the slab span was taken as $3 \mathrm{~m}$. The second cases used the same slab and deck configuration as in the analyses on symmetric beams and the slab width was taken as an upper bound of $4.5 \mathrm{~m}$. The different slab and deck depths and were analysed to identify if they had a significant effect on the additional deflection of the cellular beams relative to that of the equivalent solid web beams. 
Two load levels were considered for comparison of deflections between the theory and the FE results: either the deflection at a load corresponding to $0.5 \mathrm{P}_{\mathrm{u}}$, where $\mathrm{P}_{\mathrm{u}}$ is the failure load of the cellular beam in the FE model, or the load corresponding to a deflection of span/300. A load-deflection graph for a typical asymmetric beam with a $120 \mathrm{~mm}$ deep slab is shown in Figure 10. In the final comparisons, the deflections at a load of $0.5 \mathrm{P}_{\mathrm{u}}$ were used because of slight non-linearity at a deflection of span/300.

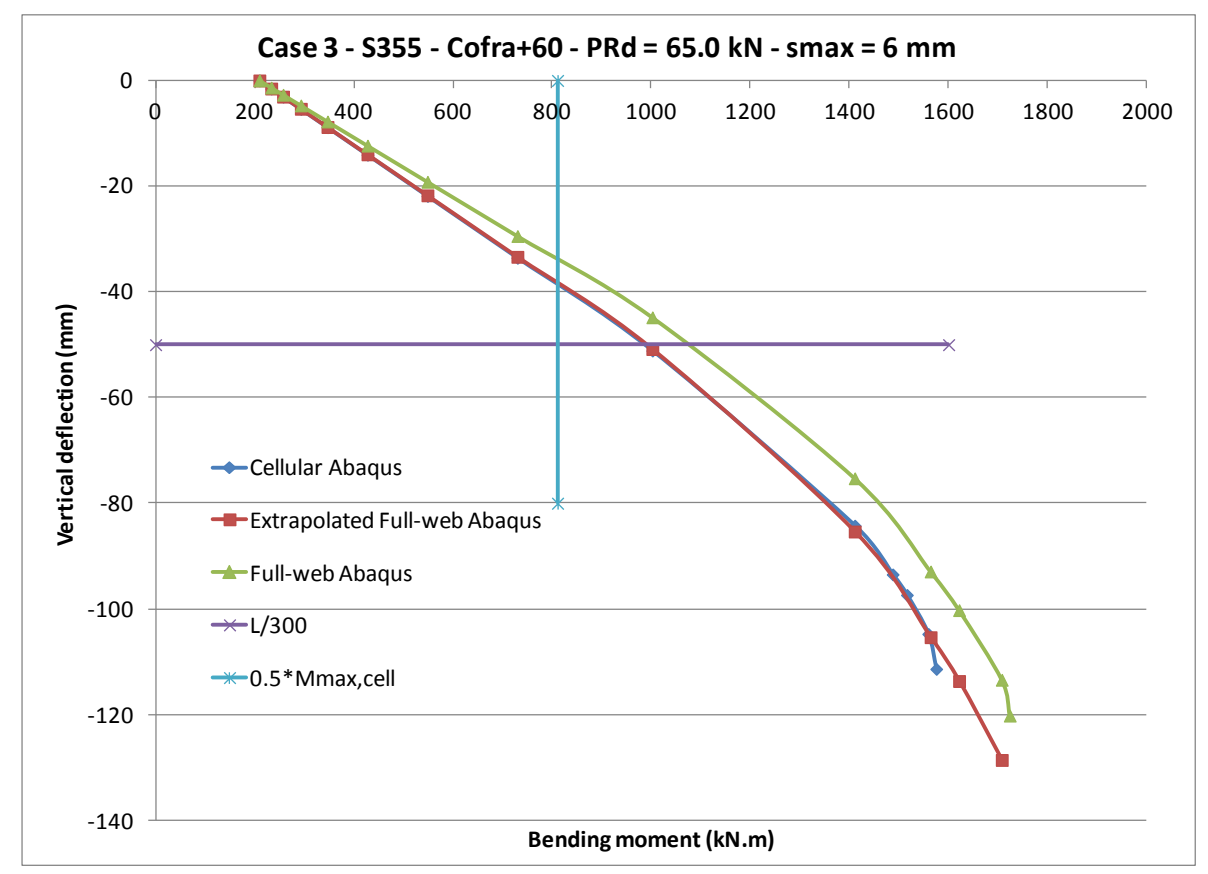

Figure 10: Load-deflection curve obtained from Abaqus for asymmetric beam of $15 \mathrm{~m}$ span using IPE 450/ HEA 450 sections

Tables 6 and 7 present the results obtained for finite element analysis of the cellular beams. The FE results give an increase in deflection due to the openings in the range of 11 to $30 \%$. The results are compared to the approximate equations (24) and (25) for the additional deflection $w_{\text {add }}$ relative to that of the solid web beam. A difference of $2 \%$ on the unconservative side between the additional deflection in the approximate method and the FEA results is considered acceptable given the small difference that this has on the total deflection (less than $0.5 \%$ ). It is shown that this approximate formulae predict an additional deflection of 14 to $35 \%$ for the asymmetric cellular beams, which agrees reasonably well with the FE results over the wide range of sections and span: depth ratios. 
Table 6: Additional deflections for asymmetric composite beams with circular openings and with $120 \mathrm{~mm}$ deep slab and $58 \mathrm{~mm}$ deep decking

\begin{tabular}{|c|c|c|c|c|c|c|c|c|c|c|}
\hline \multirow[t]{2}{*}{$\begin{array}{l}\text { Top } \\
\text { Tee }\end{array}$} & \multirow[t]{2}{*}{$\begin{array}{l}\text { Bottom } \\
\text { Tee }\end{array}$} & \multirow[t]{2}{*}{$\begin{array}{l}\text { Span, } \\
\mathrm{L}(\mathrm{m})\end{array}$} & \multicolumn{3}{|c|}{$\begin{array}{l}\text { Beam and opening } \\
\text { parameters }\end{array}$} & \multirow[t]{2}{*}{$\mathrm{n}_{\mathrm{o}}$} & \multicolumn{2}{|c|}{$\begin{array}{l}\text { Deflections } \\
\text { from FEA } \\
(\mathrm{mm})\end{array}$} & \multicolumn{2}{|c|}{$\begin{array}{c}\text { Additional } \\
\text { deflection as \% of } \\
\text { solid web beam }\end{array}$} \\
\hline & & & $\mathrm{L} / \mathrm{h}$ & $h_{0} / h$ & $\left(s . h_{0}\right) / h_{0}$ & & $\mathrm{w}_{\text {solid }}$ & $\mathrm{W}_{\text {cellular }}$ & $\begin{array}{l}\text { FEA } \\
\mathrm{w}_{\mathrm{add}}\end{array}$ & $\begin{array}{l}\text { Approx. } \\
\text { Eqns } \\
(24) \&(25)\end{array}$ \\
\hline IPE330 & HEA300 & \multirow[t]{3}{*}{10} & \multirow[t]{3}{*}{23.7} & 0.57 & 0.33 & 29 & \multirow[t]{3}{*}{21.6} & 25.6 & $18.5 \%$ & $21.1 \%$ \\
\hline \multirow{2}{*}{\multicolumn{2}{|c|}{$\begin{array}{c}\text { Asymmetry in } \\
\text { flange areas }=2.3\end{array}$}} & & & 0.66 & 0.48 & 20 & & 24.9 & $15.3 \%$ & $15.5 \%$ \\
\hline & & & & 0.76 & 0.41 & 19 & & 25.7 & $19.0 \%$ & $24.2 \%$ \\
\hline IPE450 & HEA450 & \multirow[t]{3}{*}{15} & \multirow[t]{3}{*}{27.9} & 0.56 & 0.40 & 35 & \multirow[t]{3}{*}{34.0} & 38.9 & $14.3 \%$ & $15.6 \%$ \\
\hline \multirow{2}{*}{\multicolumn{2}{|c|}{$\begin{array}{c}\text { Asymmetry in } \\
\text { flange areas }=2.3\end{array}$}} & & & 0.65 & 0.54 & 25 & & 38.8 & $14.1 \%$ & $14.0 \%$ \\
\hline & & & & 0.74 & 0.50 & 23 & & 41.1 & $20.9 \%$ & $21.0 \%$ \\
\hline HEA360 & HEB360 & \multirow[t]{3}{*}{15} & \multirow{3}{*}{31.0} & 0.58 & 0.43 & 37 & \multirow[t]{3}{*}{34.7} & 39.3 & $13.1 \%$ & $14.6 \%$ \\
\hline \multirow{2}{*}{\multicolumn{2}{|c|}{$\begin{array}{c}\text { Asymmetry in } \\
\text { flange areas }=1.3\end{array}$}} & & & 0.66 & 0.42 & 29 & & 38.6 & $11.3 \%$ & $17.2 \%$ \\
\hline & & & & 0.74 & 0.39 & 27 & & 41.6 & $20.0 \%$ & $24.3 \%$ \\
\hline
\end{tabular}

$\mathrm{n}_{\mathrm{o}}$ is the number of openings in the span

Table 7: Additional deflections for asymmetric composite beams with circular openings and with $150 \mathrm{~mm}$ deep slab and $80 \mathrm{~mm}$ deep decking

\begin{tabular}{|c|c|c|c|c|c|c|c|c|c|c|}
\hline \multirow[t]{2}{*}{$\begin{array}{l}\text { Top } \\
\text { Tee }\end{array}$} & \multirow[t]{2}{*}{$\begin{array}{l}\text { Bottom } \\
\text { Tee }\end{array}$} & \multirow[t]{2}{*}{$\begin{array}{l}\text { Span, } \\
\mathrm{L}(\mathrm{m})\end{array}$} & \multicolumn{3}{|c|}{$\begin{array}{l}\text { Beam and opening } \\
\text { parameters }\end{array}$} & \multirow[t]{2}{*}{$\mathrm{n}_{\mathrm{o}}$} & \multicolumn{2}{|c|}{$\begin{array}{l}\text { Deflections } \\
\text { from FEA } \\
(\mathrm{mm})\end{array}$} & \multicolumn{2}{|c|}{$\begin{array}{c}\text { Additional } \\
\text { deflection as } \% \text { of } \\
\text { solid web beam }\end{array}$} \\
\hline & & & $\mathrm{L} / \mathrm{h}$ & $h_{0} / h$ & $\left(\mathrm{~s} . \mathrm{h}_{\mathrm{o}}\right) / \mathrm{h}_{0}$ & & $\mathrm{w}_{\text {solid }}$ & $\mathrm{W}_{\text {cellular }}$ & $\begin{array}{l}\text { FEA } \\
w_{\text {add }}\end{array}$ & $\begin{array}{l}\text { Approx. } \\
\text { Eqns (24) } \\
\&(25)\end{array}$ \\
\hline IPE600 & HEA800 & \multirow[t]{3}{*}{18} & \multirow[t]{3}{*}{18.2} & 0.55 & 0.30 & 25 & \multirow[t]{3}{*}{30.8} & 37.6 & $22.0 \%$ & $26.8 \%$ \\
\hline \multirow{2}{*}{\multicolumn{2}{|c|}{$\begin{array}{c}\text { Asymmetry in } \\
\text { flange areas }=2.0\end{array}$}} & & & 0.65 & 0.33 & 17 & & 36.4 & $18.2 \%$ & $27.3 \%$ \\
\hline & & & & 0.75 & 0.35 & 15 & & 40.1 & $30.0 \%$ & $34.9 \%$ \\
\hline HEA450 & HEB450 & \multirow[t]{3}{*}{15} & \multirow[t]{3}{*}{24.4} & 0.57 & 0.34 & 29 & \multirow[t]{3}{*}{25.9} & 30.1 & $16.2 \%$ & $19.4 \%$ \\
\hline \multirow{2}{*}{$\begin{array}{r}\text { Asymm } \\
\text { flange ar }\end{array}$} & etry in & & & 0.67 & 0.51 & 21 & & 30.3 & $17.0 \%$ & $15.7 \%$ \\
\hline & eas $=1.2$ & & & 0.775 & 0.47 & 19 & & 32.3 & $24.7 \%$ & $23.4 \%$ \\
\hline
\end{tabular}

\section{Comparison of Theory with Test on Long Span Composite Asymmetric Beams}

A long span cellular beam was tested at the University of Bradford as part of the project, DISCCo (10), to obtain data on the performance of composite cellular beams with low degrees of shear connection at the ultimate limit state, and the test also gave good data on the serviceability performance of the beam. It was subject to 8 point loads to simulate uniform loading that was progressively increased in cycles of loading to determine the effects of slip in the serviceability and ultimate load ranges. The slab was $150 \mathrm{~mm}$ deep with an $80 \mathrm{~mm}$ deep trapezoidal deck profile, which is the same as that used in the FE models described in section 4.3. Shear connectors $(125 \mathrm{~mm}$ height and $19 \mathrm{~mm}$ diameter) were welded through the decking at a spacing of one per deck rib at $300 \mathrm{~mm}$ spacing.

A detailed paper on this test is presented by Sheehan et al. (17) and so a summary of the paper is presented here which concentrates on the serviceability performance. 


\subsection{Test Details of a Long Span Cellular Beam}

The cellular beam was $15.3 \mathrm{~m}$ span and the bottom part of the cellular beam was a HEB 360 section, and the upper part was an IPE 450 section, and so the asymmetry ratio of flange areas was 2.4:1. The resulting cellular beam depth was $565 \mathrm{~mm}$, and its span: depth ratio was 27. The calculated degree of shear connection was $38 \%$ in comparison to a Eurocode 4 requirement of $85 \%$ for this flange asymmetry.

The $425 \mathrm{~mm}$ diameter circular openings were placed at $680 \mathrm{~mm}$ spacing $(=1.6 \times$ opening diameter) and an elongated opening of $1105 \mathrm{~mm}$ length was provided at mid-span. Some openings were half in-filled at or near to load points to avoid local failure. The slab width was chosen as $3 \mathrm{~m}$ for practical test reasons. The novel use of the out-rigger beams to support the decking temporarily during construction meant that the self-weight loads were applied to the steel section to mimic un-propped construction.

The cellular beam under test is shown in Figure 11. The failure load was $17.4 \mathrm{kN} / \mathrm{m}^{2}$ when expressed as a uniformly distributed load over the slab area plus $3.6 \mathrm{kN} / \mathrm{m}^{2}$ for the self-weight of the slab and beam. The load-deflection curves for all cycles of loading are shown in Figure 12. The behaviour was elastic up to a load of about $9.5 \mathrm{kN} / \mathrm{m}^{2}$ which was $55 \%$ of the failure load of the cellular beam.

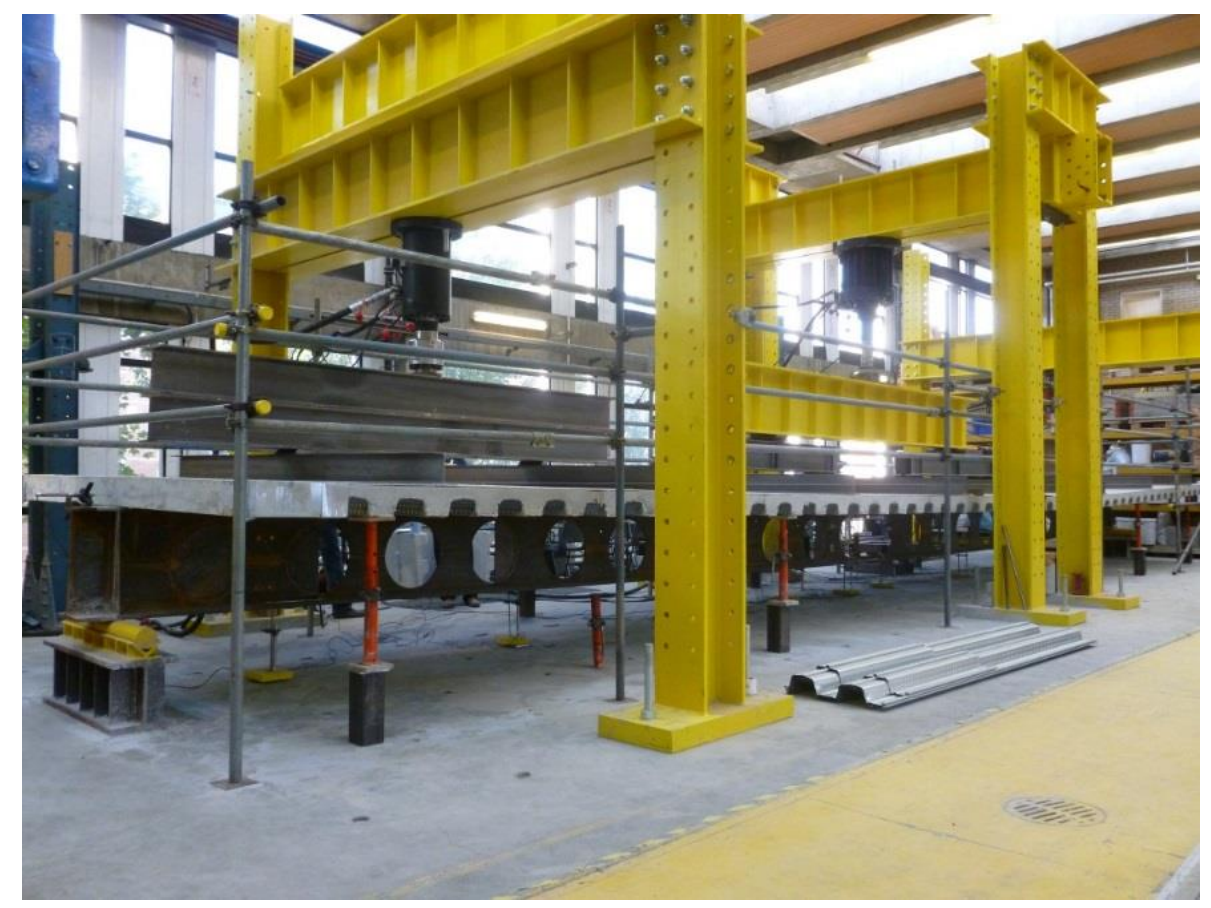

Figure 11 Cellular beam under test with 8 point loads to simulate uniform loading 


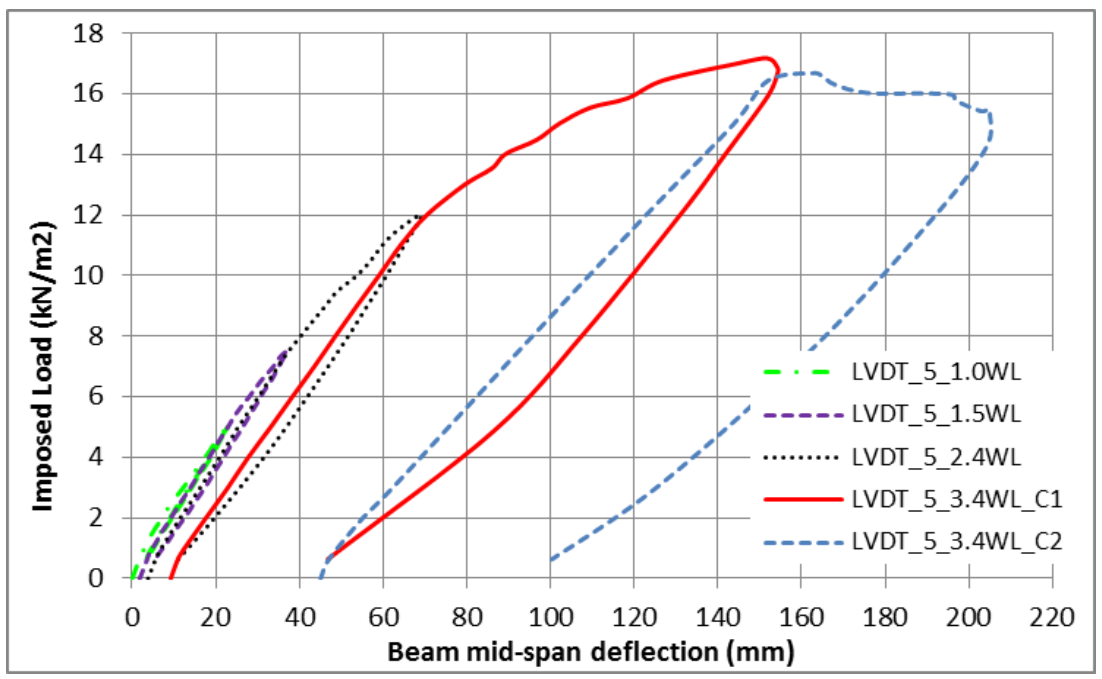

Figure 12 Load-deflection curves of the cellular beam for the 5 load cycles to failure

\subsection{Calculated inertias of cellular beam}

The calculated inertias of the steel and composite cellular beams are presented in Table 8. The composite inertia was calculated first for the solid web beam and then for the perforated beam. Two concrete topping thicknesses were considered in these calculations: a minimum depth of $55 \mathrm{~mm}$ over the stiffener at the top of the deck profile, and a depth of $70 \mathrm{~mm}$ over the top of the deck profile ignoring the stiffener, which was considered to give a more realistic slab stiffness. Both were calculated for a short term modular ratio $\left(E_{\mathrm{s}} / E_{\mathrm{c}}\right)$ of 6.5 , which is representative of the elastic modulus of the tested concrete grade.

For cellular beams with regular circular openings, the effective flexural stiffness of the composite cellular beam, $I_{\text {comp, cell }}$ may be calculated from composite inertias of the solid and perforated sections based the proportionate length of the circular openings of $0.7 h_{0}$ determined as in section 3.1, as follows:

$l_{\text {eff, cell }}=\left(l_{\text {eff,o }} \times 0.7 h_{0}+l_{\text {eff }}\left(s-0.7 h_{0}\right)\right) / s$

Where $l_{\text {eff,o }} \quad$ is the effective inertia of the composite beam at the centre of the opening

$l_{\text {eff }} \quad$ is the effective inertia of the composite solid web beam

The effective inertia of the section, $l_{\text {eff }}$ with flexible shear connectors was calculated using the areas and inertia of the steel section corresponding to the solid web and perforated sections respectively using equation (26).

To calculate the bending deflection of perforated steel beams in the construction stage, equation (26) may also be used with the properties of the perforated and solid web steel section. Using the effective inertia of $721 \times 10^{6} \mathrm{~mm}^{4}$, the deflection of the un-propped beam is $38.2 \mathrm{~mm}$ (= span/400) when subject to the self-weight of the slab $\left(=2.7 \mathrm{kN} / \mathrm{m}^{2}\right)$. This compares well to a measured deflection of $38 \mathrm{~mm}$ of the cellular beam after concreting. 
Table $8 \quad$ Calculated inertias $\left(\mathrm{mm}^{4}\right)$ of steel and composite section in the long span cellular beam test

\begin{tabular}{|l|c|c|c|c|c|c|}
\hline Section & \multicolumn{2}{|c|}{$\begin{array}{c}\text { Properties of Steel } \\
\text { Section }\end{array}$} & \multicolumn{3}{|c|}{ Second Moment of Area of Composite Section, $\mathrm{mm}^{4}$} \\
\cline { 2 - 7 } & $\begin{array}{c}\text { Second } \\
\text { moment } \\
\text { of area, } \\
\mathrm{mm}^{4}\end{array}$ & $\begin{array}{c}\text { Elastic } \\
\text { neutral } \\
\text { axis, } \mathrm{mm}\end{array}$ & \multicolumn{2}{|c|}{ Rigid shear connectors } & \multicolumn{2}{|c|}{$\begin{array}{c}\text { Flexible shear connectors } \\
\left(\mathrm{k}_{\mathrm{sc}}=70 \mathrm{kN} / \mathrm{mm}\right) \text { using } \\
\text { equation }(2)\end{array}$} \\
\cline { 4 - 7 } & $758 \times 10^{6}$ & $358 \mathrm{~mm}$ & $2965 \times 10^{6}$ & $3088 \times 10^{6}$ & $2383 \times 10^{6}$ & $2437 \times 10^{6}$ \\
\hline $\begin{array}{l}\text { Beam with } \\
\text { solid web }\end{array}$ & $675 \times 10^{6}$ & $376 \mathrm{~mm}$ & $2529 \times 10^{6}$ & $2666 \times 10^{6}$ & $2124 \times 10^{6}$ & $2211 \times 10^{6}$ \\
\hline $\begin{array}{l}\text { Beam at } \\
\text { opening }\end{array}$ & $721 \times 10^{6}$ & & $2773 \times 10^{6}$ & $2902 \times 10^{6}$ & $2269 \times 10^{6}$ & $2337 \times 10^{6}$ \\
\hline $\begin{array}{l}\text { Effective } \\
\text { stiffness, using } \\
\text { eqn (12) }\end{array}$ & & & & & & \\
\hline
\end{tabular}

Elastic neutral axis measured from top of steel section

\subsection{Comparison of test deflections with theory, FE models and code methods}

The test deflections at an imposed load of $5 \mathrm{kN} / \mathrm{m}^{2}$ are compared in Table 9 with the theory presented in this paper and with the approximate formulae in BS 5950-3. The slab topping depth is taken as $70 \mathrm{~mm}$ in these comparisons. The deflection obtained from Eurocode 4 for full shear connection would be $16.5 \mathrm{~mm}$ for a solid web beam and $17.5 \mathrm{~mm}$ using the effective bending stiffness taking account of the proportionate length of the openings.

The bending deflection of the composite cellular beam taking account of the proportionate length of the openings was calculated for shear connector stiffness of $k_{s c}=70$ and 100 $\mathrm{kN} / \mathrm{mm}$. The deflections using Equation (3) were obtained as $21.8 \mathrm{~mm}$ and $20.6 \mathrm{~mm}$ respectively, which correspond to an increase of $4.3 \mathrm{~mm}$ and $3.1 \mathrm{~mm}$ (or 24 and $18 \%$ respectively) for the two cases relative to a beam designed with rigid shear connectors to Eurocode 4.

The predicted load-displacements using the effective stiffness of the perforated beam and solid web beam for flexible shear connectors are presented in Figure 13. This shows good agreement of the use of equations (3) and (26) with the measured deflections up to a load of about $9 \mathrm{kN} / \mathrm{m}^{2}$ which is the point of non-linear behaviour of the shear connectors. This comparison ignores the additional deflection due to shear caused by the openings- see below. 


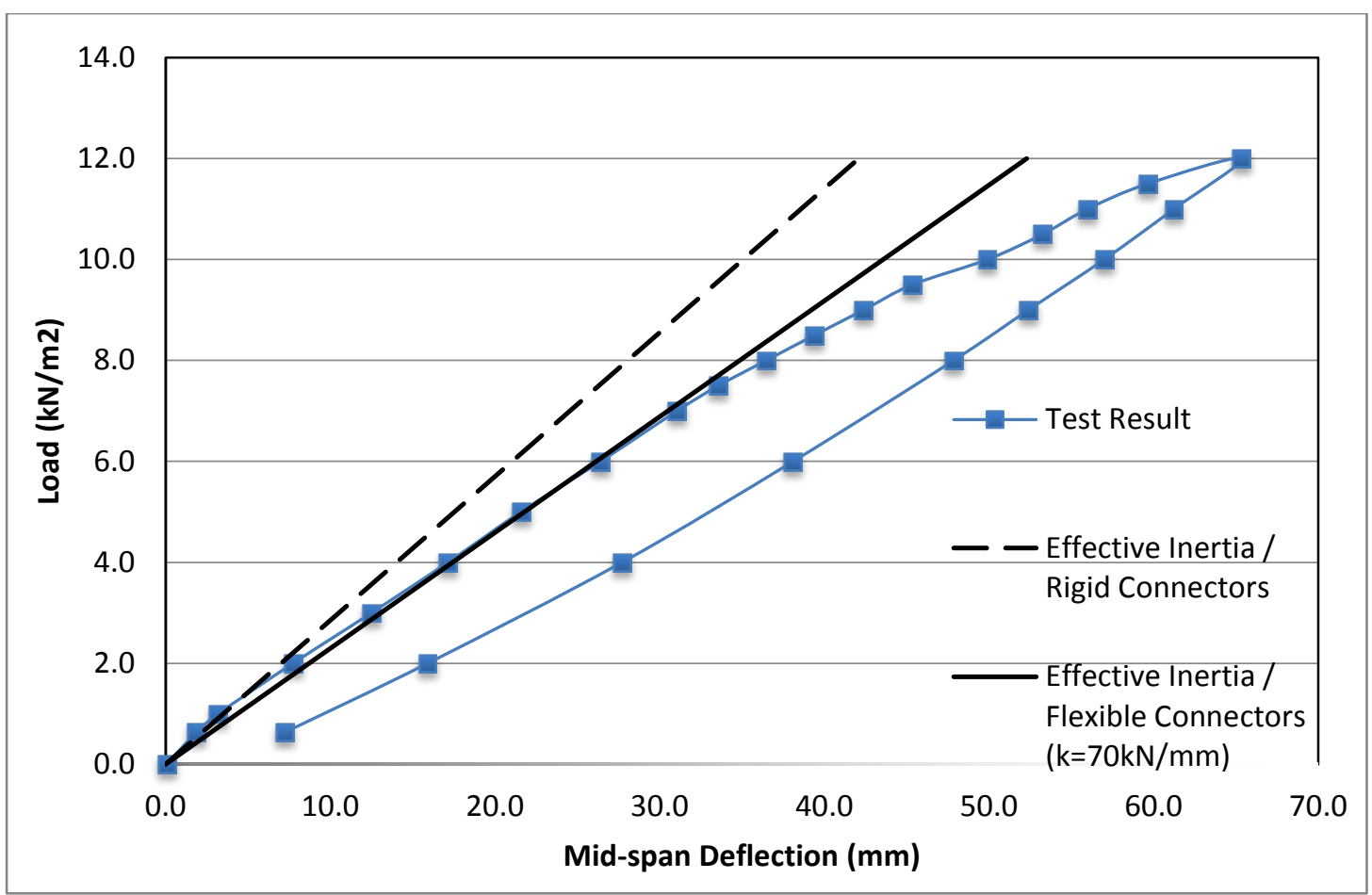

Figure 13 Load-deflection cycle of the cellular beam up to $12 \mathrm{kN} / \mathrm{m}^{2}$

Using Equation (23) with effectively, $\mathrm{n}_{\mathrm{o}}=16$ (14 circular and one elongated opening), the additional bending deflection is $10 \%$ and the additional shear deflection is $6 \%$ of the deflection of the solid web beam with rigid shear connectors. The leads to an additional deflection due to the openings of $0.16 \times 16.5=2.6 \mathrm{~mm}$ of which the shear deflection is only $1 \mathrm{~mm}$. Using the approximate Equation (24), the additional deflection is $0.14 \times 16.5=2.3 \mathrm{~mm}$.

The combined additional deflection due to the flexible shear connectors (with $\mathrm{k}_{\mathrm{sc}}=70 \mathrm{kN} / \mathrm{mm}$ ) and the effect of the openings is therefore $4.3+2.6=6.9 \mathrm{~mm}$, leading to a total deflection of $23.4 \mathrm{~mm}$, which exceeds the measured deflection of $21.6 \mathrm{~mm}$. For $\mathrm{k}_{\mathrm{sc}}=100 \mathrm{kN} / \mathrm{mm}$, the total reduces to $22.2 \mathrm{~mm}$, which is in closer agreement to the test. This shows that for this test with a span: depth ratio of 27, the measured effect of the openings is less than given by the theory in Equation (23) or the approximate Equation (24), or conversely that the effective stiffness of the shear connectors is higher than obtained from push tests.

When using the minimum concrete topping of $55 \mathrm{~mm}$, the theoretical deflection increases further, which shows that the concrete topping of $70 \mathrm{~mm}$ is more representative of the composite stiffness. The deflection obtained from the former BS $5950-3$ would be $27.3 \mathrm{~mm}$ (using equation (3)), which over-estimates the effects of deflection due to partial shear connection.

Table 9 Comparison of the test results on long span cellular beam for a load of $5 \mathrm{kN} / \mathrm{m}^{2}$

\begin{tabular}{|c|c|c|c|c|c|c|}
\hline \multirow[t]{2}{*}{ Test beam } & \multirow{2}{*}{$\begin{array}{l}\text { Degree of } \\
\text { shear } \\
\text { connection } \\
\text { in test }\end{array}$} & \multirow{2}{*}{$\begin{array}{c}\text { Measured } \\
\text { deflection } \\
\text { in test at } \\
5 \mathrm{kN} / \mathrm{m}^{2}\end{array}$} & \multirow{2}{*}{$\begin{array}{l}\text { Deflection of } \\
\text { composite } \\
\text { cellular beam } \\
\text { with rigid shear } \\
\text { connectors }\end{array}$} & \multicolumn{2}{|c|}{$\begin{array}{l}\text { Eqns (3) and (26)using } \\
\text { shear connector } \\
\text { stiffness of: }\end{array}$} & \multirow{2}{*}{$\begin{array}{l}\text { BS 5950-3 } \\
\text { using } \\
\text { additional } \\
\text { deflection } \\
\text { (eqn (2)) }\end{array}$} \\
\hline & & & & $\begin{array}{l}\mathrm{k}_{\mathrm{sc}}=70 \\
\mathrm{kN} / \mathrm{mm}\end{array}$ & $\begin{array}{c}\mathrm{k}_{\mathrm{sc}}=100 \\
\mathrm{kN} / \mathrm{mm}\end{array}$ & \\
\hline
\end{tabular}


$15.3 \mathrm{~m}$ span asymmetric cellular beam

\begin{tabular}{|c|c|}
\hline $38 \%$ & $21.6 \mathrm{~mm}$ \\
\hline
\end{tabular}

The stiffness of a cellular beam is based on the proportionate length of the openings in equation (26)

The load-deflection graphs obtained from the ANSYS and Abaqus finite element models presented earlier were compared to the test results and also the plastic bending resistance, $M_{p l}$ calculated using measured material strengths. The comparison is shown in Figure 14, which demonstrates good agreement, particularly in the elastic range. This also shows that the elasto-plastic behaviour also modelled with reasonable accuracy taking account of the declining stiffness of the shear connectors in Figure 7.

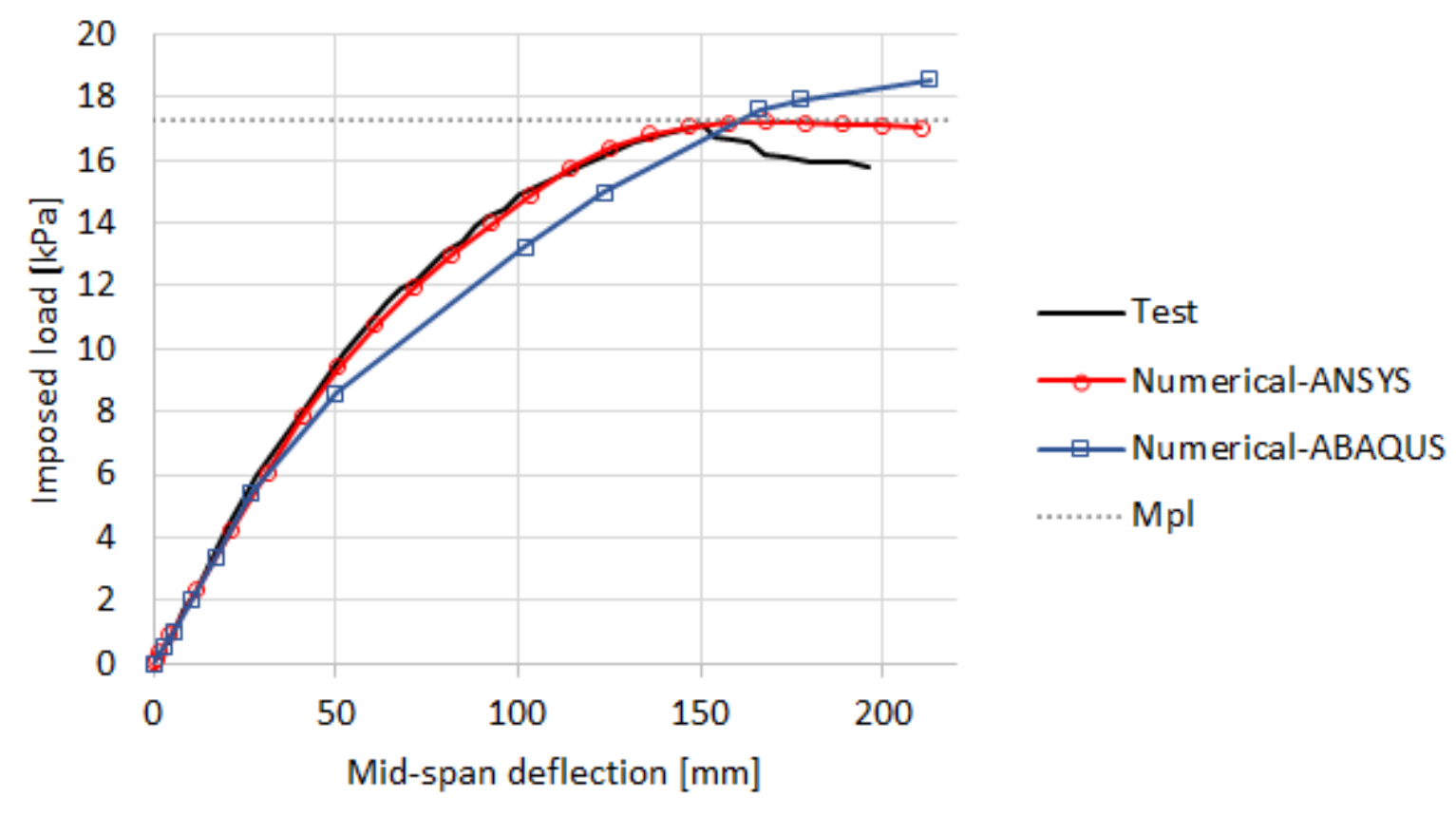

Figure 14: Comparison of the ANSYS and Abaqus finite element models for the $15.3 \mathrm{~m}$ span cellular beam

\section{Conclusions}

Approximate design formulae are presented for the increase of deflection, $w_{\text {add }}$, of perforated composite beams with a series of $n_{0}$ circular openings in comparison to the deflection of equivalent composite beams of the same proportions and loading, $w_{b}$, which are as follows:

$$
\begin{array}{ll}
\frac{w_{\text {add }}}{w_{b}}=3 n_{o}\left(\frac{h_{o}}{h}\right)^{3}\left(\frac{h}{L}\right)^{1.5} \quad \text { for } \mathrm{s}>1.5 \mathrm{~h}_{\circ} \\
\frac{w_{\text {add }}}{w_{b}}=1.5 n_{o}\left(\frac{h_{o}}{h}\right)^{3}\left(\frac{h_{o}}{s-h_{o}}\right)\left(\frac{h}{L}\right)^{1.5} \text { for } \mathrm{s}<1.5 \mathrm{~h}_{\circ}
\end{array}
$$

The above formulae are shown to be reasonably accurate for design purposes based on the comparison with the results of finite element analyses of composite cellular beams of different proportions and also with a more accurate theory based on the increase in deflection due to 
bending and shear. The proposed limits of application of the formulae are presented as follows;

- Beams with uniformly distributed loading or multiple point loads

- Beam span: depth ratio in the range of $30 \geq \mathrm{L} / \mathrm{h} \geq 18$, the lower limit applying so that shear effects do not dominate

- Opening diameter $\leq 0.75 x$ Beam depth

- Opening spacing (based on centre-line of openings) $\geq 1.3 \times$ Opening diameter

- Slab depth between $15 \%$ and $25 \%$ of the beam depth

The results are also compared with deflections obtained a $15.3 \mathrm{~m}$ span cellular beam test and are shown to be conservative when based on the effective bending properties of the composite beam in which the effective opening length is taken as $70 \%$ of the opening. The shear connectors stiffness was taken as $70 \mathrm{kN} / \mathrm{mm}$, based on the results of push tests.

For composite cellular beams designed for partial shear connection, it is shown that the additional deflection due to the flexibility of the shear connectors can exceed the additional deflection due to the series of circular openings. It is also shown that additional deflections due to effects of shear on the openings may be neglected for composite cellular beams with span: depth ratios exceeding 25 .

The increase in deflection of composite cellular beams compared to the equivalent composite solid web beams is typically in the range of 15 to $25 \%$, depending on the proportionate height and the spacing of the openings. As an approximation for modelling of composite beams with circular openings, the effective length of the opening may be taken as $0.7 x$ opening diameter when determining the proportionate bending and shear stiffness of the composite section at an opening. 


\section{References}

(1) BS EN 1994-1-1, Eurocode 4: Design of Composite Steel and Concrete Structures, Part 1.1 General Rules and Rules for Buildings, British Standards Institution, 2004

(2) BS 5950: Structural Use of Steelwork in Buildings, Part 3 Design in Composite Construction. Section 3.1 Code of Practice for Design of Simple and Continuous Composite Beams, 1990 including Amendments 2010, British Standards Institution

(3) AISC 360-10, Specification for Structural Steel Buildings, American Institute of Steel Construction, Manual of Steel Construction, 2010.

(4) Lawson R.M. and Hicks S.J, Design of Composite Beams with Large Web Openings, SCI P355, 2011, The Steel Construction Institute, Ascot, UK

(5) Darwin D, Design of Steel and Composite Beams with Web Openings, Steel Design Guide Series 2, American Iron and Steel Institute, 1990

(6) Couchman G, Minimum Degree of Shear Connection Rules for UK Construction to Eurocode 4, Electronic Publication 405, 2015, The Steel Construction Institute, Ascot, UK.

(7) Lawson RM, Lam D, Aggelopoulos E, and Nellinger S, Serviceability Performance of Composite Beams, Proc. Inst. Civil Engineers Structures and Buildings, to be published, 2016

(8) Lawson R.M., Hicks S.J. and Simms W.I., Design of Composite Asymmetric Cellular Beams and Beams with Large Web Openings, Journal Constr. Steel Research 62, 6, 206, p 614-629

(9) Redwood. R. and Cho. S. H., (1993): 'Design of Steel and Composite beams with web openings', Journal of Constructional Steel Research, Volume 25, 23-41.

(10) Research Fund for Coal and Steel, Final Report of RFCS Project DISCCo 'Development of Improved Shear Connection Rules in Composite Beams' RFSR-CT-2012-00030 (to be published by the European Commission), 2016

(11) BS EN 1993-1-1: Eurocode 3 Design of Steel Structures Part 1.1 General Rules and Rules for Buildings, British Standards Institution, 2005

(12) Newmark N.M, Siess C. P and Viesst I.M., Tests and Analysis of Composite Beams with Incomplete Shear Connection, Proc. Soc. Experimental Stress Analysis 9 (1), 1951

(13) Lam D, Elliott K.S., and Nethercot D.A, Designing composite steel beams with precast concrete hollow-core slabs, Proc Inst. Civil Engs, Structures and Buildings May 2000, 140, p139-149

(14) Ranzi G and Zona A, A Steel-Concrete Composite Beam Model with Partial Interaction Including Shear Deformability of the Steel Component, Engineering Structures 29, 2007, p $3026-3041$

(15) Ranzi G, Bradford M, and Uy B, A General Method of Analysis of Composite Beams with Partial Interaction, Steel and Composite Structures, 3, 2003 p 169-184

(16) BS EN 1992-1-1 Eurocode 2: Design of concrete structures - Part 1-1: General rules and rules for buildings, 2004 
(17) Sheehan T, Dai X, Lam D, Aggelopoulos E, Lawson R M and Obiala R (2016) Experimental Study on Long Spanning Composite Cellular Beam under Flexure and Shear, Journal Constr. Steel Research 116 p 40-54

\section{Acknowledgement}

The testing was performed at the University of Bradford under the RFCS project DISCCo 'Development of Improved Shear Connection Rules in Composite Beams' RFSR-CT-201200030 


\section{List of Tables}

Table 1: Influence of opening size on bending deflection of a composite beam using rolled sections with cut web openings for openings of proportionate depth, $h_{0} / h$

Table 2: Influence of opening size on bending deflection of a composite cellular beams for web openings of proportionate depth $h_{0} / h$

Table 3: Deflections for typical long span beams using IPE 500 sections for both cut circular openings and cut and re-welded cellular beams obtained from equations (21) and (22)

Table 4 Data for composite beams with cut openings in the FE models

Table 5 Comparison of deflections $(\mathrm{mm})$ of solid web beams and cellular beams from FEA, and theory for rigid and flexible shear connectors

Table 6: Additional deflections for asymmetric composite beams with circular openings and with $58 \mathrm{~mm}$ deep decking and $120 \mathrm{~mm}$ deep slab

Table 7: Additional deflections for asymmetric composite beams with circular openings and with $80 \mathrm{~mm}$ deep decking and $150 \mathrm{~mm}$ deep slab

Table 8 Calculated inertias $\left(\mathrm{mm}^{4}\right)$ of steel and composite section in the long span cellular beam test

Table 9 Comparison of the test results on long span cellular beam for a load of $5 \mathrm{kN} / \mathrm{m}^{2}$ 


\section{List of Figures}

Figure 1 Cellular beams with large web openings used as long span secondary beams

Figure 2 Fabrication of asymmetric cellular beam

Figure 3 Integration around openings using polar coordinates

Figure 4: Effective opening length for calculation of additional bending and shear deflections

Figure 5: Effective opening height for calculation of additional shear deflections due to web post bending

Figure 6: Effective opening height for calculation of additional shear deflections due to web post bending

Figure 7: Modelling of the shear connectors used in the finite element (FE) analyses

Figure 8: Tri-linear relationship for shear connectors used in the FE models

Figure 9: Tri-linear and parabolic stress-strain relationships for concrete used in the FE models

Figure 10: Load-deflection curve obtained from Abaqus for asymmetric beam of $15 \mathrm{~m}$ span using IPE 450/ HEA 450 sections

Figure 11: Cellular beam under test with 8 point loads to simulate uniform loading

Figure 12: Load-deflection curves of the cellular beam for the 5 load cycles to failure

Figure 13 Load-deflection cycle of the cellular beam up to $12 \mathrm{kN} / \mathrm{m}^{2}$

Figure 14: Comparison of the Ansys and ABAQUS finite element models for the $15.3 \mathrm{~m}$ span cellular beam 
